\title{
Effects of replacing canola meal as the major protein source with wheat dried distillers grains with solubles on ruminal function, microbial protein synthesis, omasal flow, and milk production in cows
}

\author{
G. E. Chibisa, D. A. Christensen, and T. Mutsvangwa ${ }^{1}$ \\ Department of Animal and Poultry Science, University of Saskatchewan, Saskatoon, SK, Canada, S7N 5A8
}

\begin{abstract}
A study was conducted to determine the effects of replacing canola meal $(\mathrm{CM})$ as the major protein source with wheat-based dried distillers grains with solubles (W-DDGS) on ruminal fermentation, microbial protein production, omasal nutrient flow and animal performance. Eight lactating dairy cows were fed in a replicated $4 \times 4$ Latin square design with 28 -d periods (20 $\mathrm{d}$ of dietary adaptation and $8 \mathrm{~d}$ of measurements). Four cows in one Latin square were ruminally cannulated for measurements of ruminal fermentation characteristics and flow of nutrients at the omasal canal. Cows were fed either a standard barley silage-based total mixed ration containing $\mathrm{CM}$ as the major protein supplement (0\% W-DDGS, control) or diets formulated to contain 10, 15, and 20\% W-DDGS (dry matter basis), with WDDGS replacing primarily CM. Diets were isonitrogenous $(18.9 \%$ crude protein) and contained 3.0, 3.2, 3.5, and $3.7 \%$ ether extract for $0,10,15$, and $20 \%$ W-DDGS, respectively. Diets contained $50 \%$ forage and $50 \%$ concentrate. Inclusion of W-DDGS linearly increased dry matter intake $(29.5,31.2,30.2$, and $31.9 \mathrm{~kg} / \mathrm{d}$ for 0,10 , 15 , and $20 \% \mathrm{~W}$-DDGS, respectively). The addition of W-DDGS in place of CM resulted in a $1.2-$ to $1.8-\mathrm{kg}$ increase in milk yield $(42.9,44.7,44.1$, and $44.5 \mathrm{~kg} / \mathrm{d}$ for $0,10,15$, and $20 \% \mathrm{~W}$-DDGS); however, a quadratic change in feed efficiency (i.e., milk yield/DM intake) occurred as the dietary level of W-DDGS increased. Treatments did not differ for milk fat, protein, and lactose concentrations; however, quadratic changes were observed in milk yields of fat $(1.48,1.56,1.62$, and 1.55 $\mathrm{kg} / \mathrm{d}$ for $0,10,15$, and $20 \% \mathrm{~W}$-DDGS, respectively), protein $(1.44,1.46,1.49$, and $1.42 \mathrm{~kg} / \mathrm{d})$ and lactose $(1.96,2.02,2.09$, and $1.93 \mathrm{~kg} / \mathrm{d})$. Ruminal fermentation characteristics did not change except that the inclusion of $20 \% \mathrm{~W}$-DDGS resulted in a decrease and a tendency for a decrease in molar concentrations of isobutyrate and total volatile fatty acids, respectively. Omasal flow
\end{abstract}

Received July 11, 2011.

Accepted October 20, 2011

${ }^{1}$ Corresponding author: tim.mutsvan@usask.ca of total bacterial nonammonia $\mathrm{N}(\mathrm{NAN})$ and bacterial efficiency ( $\mathrm{g}$ of total bacterial NAN flow $/ \mathrm{kg}$ of organic matter truly digested in the rumen) were not different among diets; however, feeding W-DDGS resulted in a quadratic increase in nonammonia nonbacterial $\mathrm{N}$ flow at the omasal canal $(271,318,336$, and $311 \mathrm{~g} / \mathrm{d}$ for $0,10,15$, and $20 \% \mathrm{~W}$-DDGS, respectively). These data indicate that W-DDGS can substitute for CM as the major protein source in dairy cow diets without negatively affecting ruminal fermentation, microbial protein production, and omasal nutrient flow, and can potentially increase dry matter intake and milk yield. Key words: wheat-based dried distillers grains with solubles, canola meal, nutrient supply, milk production

\section{INTRODUCTION}

The use of wheat as the principal feedstock for ethanol production in western Canada has led to an increase in the availability of wheat-based dried distillers grains with solubles (W-DDGS). Numerous studies conducted mostly in the United States have demonstrated that corn-based dried distillers grains with solubles (C-DDGS) can be used as a suitable replacement for traditional protein supplements while maintaining or increasing levels of milk production (reviewed by Schingoethe et al., 2009). However, compared with C-DDGS, W-DDGS contains less fat (49.8 vs. $165.3 \mathrm{~g} / \mathrm{kg})$ and more CP (393.2 g/kg vs. $320.1 \mathrm{~g} / \mathrm{kg}$ ) (Nuez-Ortín and $\mathrm{Yu}, 2009)$. Therefore, it is plausible that because of these differences in nutrient composition, the feeding value of W-DDGS for dairy cows could be different from that of C-DDGS. To date, limited research has been done on the utilization of W-DDGS in barley-based dairy diets that are commonly fed in western Canada. Because W-DDGS is high in NDF content, ranging from 25.9 to $54.1 \%$ (Dong et al., 1987; McKinnon and Walker, 2008), and this NDF is highly digestible (Nuez-Ortín and $\mathrm{Yu}, 2009$ ), a limited number of studies have examined the inclusion of W-DDGS in dairy diets as a partial replacement for forage (Penner et al., 2009; Zhang et al., 2010a,b) or barley grain (Zhang et al., 2010b). The major focus of these previous studies was to determine 
if feeding W-DDGS could attenuate ruminal acidosis. To our knowledge, no reported studies have examined the effects of replacing traditional protein supplements such as canola meal (CM) with W-DDGS on N utilization, microbial protein production, and omasal flow of nitrogenous compounds.

In western Canada and parts of the United States, $\mathrm{CM}$ is the principal source of protein included in dairy diets because it is readily available and is a high quality protein supplement (Hickling, 2008; Mulrooney et al., 2009). Recently, however, focus has turned to the use of W-DDGS in dairy diets as a strategy to control rising feed costs because W-DDGS is usually cheaper than CM (Hickling, 2008). When compared with CM, $\mathrm{W}$-DDGS is greater in CP content (43.6 vs. $39.5 \%$ ), but is lower in methionine (1.75 vs. $2.68 \mathrm{~g} / 16 \mathrm{~g}$ of $\mathrm{N}$ ) and, particularly, lysine (2.04 vs. $5.30 \mathrm{~g} / 16 \mathrm{~g}$ of $\mathrm{N}$ ) contents (Boila and Ingalls, 1994). In an in situ study, ruminal $\mathrm{N}$ degradability of W-DDGS was much lower (36.5 vs. $63.4 \%$ ), whereas small intestinal digestibility (calculated as ileal disappearance minus ruminal disappearance) was much greater ( 57.5 vs. $26.6 \%$ ) compared with CM (Boila and Ingalls, 1994). Because of the differences in RDP content of these 2 protein supplements, replacement of CM with W-DDGS may negatively affect ruminal microbial protein production. Maximizing the supply of microbial protein is important as it can contribute more than $60 \%$ of MP reaching the small intestine and, qualitatively, it has an AA profile that closely matches AA requirements for milk protein synthesis (NRC, 2001). Therefore, if substituting CM with W-DDGS compromises microbial protein synthesis due to deficiencies in RDP, this would be undesirable as it could negatively affect cow performance. Besides their requirement for microbial protein, high-producing dairy cows also require digestible RUP to augment the AA supply from microbial protein (Stern et al., 2006). Although W-DDGS is a good source of digestible RUP, its content of lysine is low (Boila and Ingalls, 1994). Therefore, another concern when replacing CM with WDDGS in lactating cow diets is whether metabolizable lysine supply will be adequate to support milk and milk protein production (Boila and Ingalls, 1994). Despite these potential challenges in meeting MP requirements when including W-DDGS in dairy cow diets, limited research has been conducted to justify either partial or complete replacement of CM with W-DDGS. Therefore, this study was conducted to determine whether completely replacing CM (as the major protein source) in barley-based rations with increasing amounts of WDDGS would have any effect on ruminal fermentation characteristics, microbial protein production, omasal flow of nitrogenous fractions, and productivity of lactating dairy cows.

\section{MATERIALS AND METHODS}

\section{Animals and Experimental Design}

Eight multiparous Holstein cows $(718.5 \pm 53.8 \mathrm{~kg}$ of BW; $101.1 \pm 39.2$ DIM) housed at the Greenbrae Dairy Research Facility (University of Saskatchewan) were used in this study. The experimental design was a replicated $4 \times 4$ Latin square with 28 -d periods $(20 \mathrm{~d}$ of dietary adaptation and $8 \mathrm{~d}$ of measurements). Four cows in one Latin square were ruminally cannulated. All experimental cows were housed in individual tiestalls and the experimental procedures used were approved by the University of Saskatchewan Animal Care Committee (UCACS Protocol No. 20040048), and were in accordance with the Canadian Council of Animal Care guidelines (Ottawa, ON, Canada).

\section{Experimental Treatments and Animal Management}

The 4 dietary treatments consisted of a standard barley silage-based diet containing $\mathrm{CM}$ as the principal protein supplement (control, 0\% W-DDGS) or diets formulated to contain 10, 15, and 20\% W-DDGS (DM basis). Single batches of CM and W-DDGS were used for the entire study. The batch of W-DDGS was produced from $100 \%$ wheat (Terra Grain Fuels, Belle Plaine, SK, Canada). Because W-DDGS has a higher CP content than CM, W-DGGS replaced all CM and varying proportions of soybean meal in the concentrate portion of diets containing W-DDGS to make diets isonitrogenous. The ingredient and chemical composition of the 4 diets is given in Table 1 . Cows were fed experimental diets as TMR at 0830 and $1600 \mathrm{~h}$ for ad libitum intake. The forage:concentrate ratio of the TMR was 50:50. The forage component of the TMR was a mixture of barley silage (65\% on a DM basis) and chopped alfalfa hay (35\%).

\section{Data Collection and Sampling}

Ruminal fermentation characteristics, microbial protein production, omasal nutrient flow, total-tract nutrient digestion, and $\mathrm{N}$ balance were determined using the 4 ruminally cannulated cows in one Latin square. To quantify omasal digesta flow, indigestible NDF (iNDF; Reynal et al., 2005), $\mathrm{YbCl}_{3}$ (Siddons et al., 1985), and CrEDTA (Udén et al., 1980) were used as digesta markers for the large particle $(\mathbf{L P})$, small particle (SP), and fluid (FP) phases, respectively. To quantify ruminal microbial protein production, $\left({ }^{15} \mathrm{NH}_{4}\right)_{2} \mathrm{SO}_{4}[10$ atom percent excess (APE) ${ }^{15} \mathrm{~N}$; Cambridge Isotope Laboratories, Andover, MA] was used as a microbial marker (Reynal et al., 2005). Preceding infusion of the marker 
Table 1. Ingredient and chemical composition of experimental diets containing wheat-based dried distillers grains with solubles (DDGS) fed to lactating dairy cows

\begin{tabular}{|c|c|c|c|c|}
\hline \multirow[b]{2}{*}{ Item } & \multicolumn{4}{|c|}{ Diet } \\
\hline & Control & $10 \%$ DDGS & $15 \%$ DDGS & $20 \%$ DDGS \\
\hline \multicolumn{5}{|c|}{ Ingredient composition, $\%$ of diet DM } \\
\hline Barley silage & 32.3 & 32.3 & 32.3 & 32.3 \\
\hline Alfalfa hay & 17.4 & 17.4 & 17.4 & 17.4 \\
\hline Barley & 30.0 & 30.3 & 29.6 & 28.4 \\
\hline Wheat-based DDGS & - & 10.0 & 15.0 & 20.0 \\
\hline Canola meal & 8.8 & - & - & - \\
\hline Soybean meal & 6.8 & 6.4 & 2.6 & - \\
\hline Corn gluten meal & 0.96 & 0.96 & 0.96 & 0.34 \\
\hline Canola oil & 0.55 & 0.55 & 0.55 & 0.55 \\
\hline Molasses & 0.22 & 0.22 & 0.22 & 0.22 \\
\hline Mineral-vitamin $\operatorname{mix}^{1}$ & 1.6 & 1.6 & 1.6 & 1.6 \\
\hline Bicarbonate & 0.88 & 0.88 & 0.88 & 0.88 \\
\hline Salt (cobalt-iodine) & 0.33 & 0.33 & 0.33 & 0.33 \\
\hline Limestone & 0.05 & 0.22 & 0.22 & 0.27 \\
\hline Dynamate $^{2}$ & 0.16 & 0.16 & 0.16 & 0.16 \\
\hline \multicolumn{5}{|l|}{ Chemical composition } \\
\hline DM, \% & 53.2 & 53.5 & 53.7 & 54.0 \\
\hline $\mathrm{OM}, \%$ of DM & 97.6 & 97.7 & 97.6 & 97.6 \\
\hline $\mathrm{CP}, \%$ of $\mathrm{DM}$ & 18.9 & 18.8 & 19.0 & 18.9 \\
\hline $\mathrm{NDF}, \%$ of DM & 32.6 & 32.3 & 32.8 & 33.6 \\
\hline $\mathrm{ADF}, \%$ of DM & 18.0 & 17.8 & 18.5 & 19.0 \\
\hline $\mathrm{RDP}^{3} \%$ of DM & 12.7 & 13.0 & 11.0 & 11.6 \\
\hline $\mathrm{RUP}^{4} \%$ of DM & 6.64 & 7.28 & 7.55 & 7.52 \\
\hline Ether extract, $\%$ of DM & 3.0 & 3.2 & 3.5 & 3.7 \\
\hline $\mathrm{NE}_{\mathrm{L}},{ }^{5} \mathrm{Mcal} / \mathrm{kg}$ of $\mathrm{DM}$ & 1.5 & 1.5 & 1.5 & 1.5 \\
\hline
\end{tabular}

${ }^{1}$ Contained (per kilogram of premix; DM basis): 330,000 IU of vitamin A, 60,000 IU of vitamin D, 1,000 IU of vitamin E, $16 \%, \mathrm{Ca}, 8.5 \% \mathrm{P}, 6.3 \% \mathrm{Na}, 4.5 \% \mathrm{Mg}, 2,100 \mathrm{mg}$ of $\mathrm{Zn}, 1,500 \mathrm{mg}$ of $\mathrm{Mn}, 535 \mathrm{mg}$ of Cu, $12 \mathrm{mg}$ of Se, $45 \mathrm{mg}$ of I.

${ }^{2}$ Dynamate (Eastern Minerals Inc., Henderson, NC) contained $18 \% \mathrm{~K}, 11 \% \mathrm{Mg}$, and $22 \% \mathrm{~S}$.

${ }^{3} \mathrm{RDP}$ was calculated from in vivo measurements as RDP, $\%$ of DM $=$ (total $\mathrm{CP}$ intake, $\mathrm{kg} / \mathrm{d}-$ omasal RUP flow, $\mathrm{kg} / \mathrm{d}) \times 100 / \mathrm{DM}$ intake, $\mathrm{kg} / \mathrm{d}$.

${ }^{4} \mathrm{RUP}$ was calculated from in vivo measurements as RUP, \% of DM = (total omasal CP flow, $\mathrm{kg} / \mathrm{d}-$ omasal microbial CP flow, $\mathrm{kg} / \mathrm{d}$ ) $\times 100 / \mathrm{DM}$ intake, $\mathrm{kg} / \mathrm{d}$.

${ }^{5}$ Calculated from NRC (2001).

solutions (d 13), a 500-mL rumen digesta sample was collected and stored at $-20^{\circ} \mathrm{C}$ for the determination of background ${ }^{15} \mathrm{~N}\left({ }^{15} \mathrm{NB}\right)$ abundance. A priming dose of the 3 marker solutions $\left[\mathrm{YbCl}_{3},\left({ }^{15} \mathrm{NH}_{4}\right)_{2} \mathrm{SO}_{4}\right.$, and Cr-EDTA] equivalent to half the daily dose was then administered into the rumen via the ruminal cannula. Subsequently, marker solutions were continuously infused into the rumen using a peristaltic pump (model 205U, Watson and Marlow, Cornwall, UK) for the next $10 \mathrm{~d}$ (d 13 to 23 ) at a constant rate of $1 \mathrm{~L} / \mathrm{d}$, providing $2.77 \mathrm{~g}$ of $\mathrm{Cr}$ (Binnerts et al., 1968), $3.35 \mathrm{~g}$ of $\mathrm{Yb}$, and $0.22 \mathrm{~g}$ of ${ }^{15} \mathrm{~N}$ (Brito et al., 2006) per day. The amount of marker solution infused each day $(\sim 1 \mathrm{~L})$ was recorded. During each period, a $50-\mathrm{mL}$ subsample of the marker solutions infused for each cow was collected and stored at room temperature for $\mathrm{Cr}, \mathrm{Yb}$, and ${ }^{15} \mathrm{~N}$ analysis.

The omasal sampling technique as described by Huhtanen et al. (1997) was used to collect omasal digesta. Briefly, this technique involved locating the omasal canal by hand and then inserting a sampling tube via the ruminal cannula. Sampling tubes were inserted at each sampling time to ensure correct positioning in the omasal canal and to minimize the potential negative effect on digesta passage and normal digestive function if the sampling tubes were left in place between samplings. Once the sampling tube had been inserted in the omasal canal, a $425-\mathrm{mL}$ omasal digesta sample was collected from each cow at 0600,1200, and $1800 \mathrm{~h}$ on d 20; 0000, 0800, 1400, and $2000 \mathrm{~h}$ on d 21;0200, 1000, 1600 , and $2200 \mathrm{~h}$ on d 22; and $0400 \mathrm{~h}$ on d 23 , such that the collected samples were representative of a $24-\mathrm{h}$ feeding cycle. After careful mixing to ensure representative sampling, the collected $425-\mathrm{mL}$ sample was divided into 100-, 125-, and 200-mL subsamples. The 100- and 200-mL subsamples were immediately stored at $-20^{\circ} \mathrm{C}$, and were pooled by cow over the 24 -h cycle to yield 1.2 and 2.4-L composite samples, respectively. The $125-\mathrm{mL}$ subsamples were placed in an ice-bath following collection, and pooled over 2 sampling times to yield a 250 $\mathrm{mL}$ composite sample that was used for the isolation of 
particle-associated (PAB) and fluid-associated (FAB) bacteria using filtration and differential centrifugation as described by Brito et al. (2009). Briefly, the 250-mL composite samples were squeezed through 2 layers of cheesecloth. The resultant filtrand (solids) was washed with $250 \mathrm{~mL}$ of $0.85 \%$ saline solution, squeezed again through 2 layers of cheesecloth, and then transferred to a $500-\mathrm{mL}$ PAB container that contained $175 \mathrm{~mL}$ of a cold $\left(5^{\circ} \mathrm{C}\right) \quad 0.85 \%$ saline solution with $0.1 \%$ (wt/ vol) Tween-80. The contents of the PAB container were then mixed thoroughly and held on ice. The filtrate from these initial filtration steps was collected, pooled, and held on ice in preparation for the isolation of FAB. To isolate $\mathrm{FAB}$, the filtrate was initially centrifuged $\left(1,000 \times g, 5^{\circ} \mathrm{C}, 5 \mathrm{~min}\right)$. The resultant pellet was transferred to the $\mathrm{PAB}$ container, whose contents were then blended on low speed for $30 \mathrm{~s}$ before storage at $5^{\circ} \mathrm{C}$ until PAB isolation $24 \mathrm{~h}$ later. The supernatant was decanted and centrifuged $\left(11,300 \times g, 5^{\circ} \mathrm{C}, 30 \mathrm{~min}\right)$. Following centrifugation, the resultant supernatant was decanted and discarded, whereas the pellet was resuspended in $50 \mathrm{~mL}$ of McDougall's buffer (McDougall, 1948). The suspension was then recentrifuged $(11,300$ $\left.\times g, 5^{\circ} \mathrm{C}, 30 \mathrm{~min}\right)$, and the resultant $\mathrm{FAB}$ pellet was stored at $-20^{\circ} \mathrm{C}$. Following storage at $5^{\circ} \mathrm{C}$ for $24 \mathrm{~h}$, contents of the PAB container were filtered through 2 layers of cheesecloth. The filtrate was then processed as described previously for FAB isolation, with the exception that the pellet obtained after the initial low speed centrifugation $\left(1,000 \times g, 5^{\circ} \mathrm{C}, 5 \mathrm{~min}\right)$ step was discarded. The resultant $\mathrm{PAB}$ pellet was then stored at $-20^{\circ} \mathrm{C}$.

Apparent total-tract nutrient digestibility and $\mathrm{N}$ balance were determined using 4-d total urine and feces collection as described by Plaizier et al. (2000), starting on d 24 of each experimental period. Total urine output was collected using indwelling Bardex Foley bladder catheters (26 Fr, 75-mL ribbed balloon, lubricious-coated; C. R. Bard Inc., Covington, GA). Catheters were inserted at $0900 \mathrm{~h}$ on $\mathrm{d} 23$, and were then connected to urine collection tubing when urine collections were initiated at $0900 \mathrm{~h}$ on $\mathrm{d} 24$. Urine was collected into 20-L Carboy polyethylene containers into which 200 $\mathrm{mL}$ of $\mathrm{H}_{2} \mathrm{SO}_{4}$ had been added to achieve urine $\mathrm{pH}$ of less than 3 . The acidification of urine was necessary to prevent microbial degradation and the loss of volatile $\mathrm{NH}_{3}-\mathrm{N}$. Daily urinary output was weighed and mixed thoroughly, and a 5\% subsample of the daily output was drawn, pooled for each cow during each collection period, and stored at $-20^{\circ} \mathrm{C}$ until analyzed for total $\mathrm{N}$. In addition, a 2-mL aliquot of urine was diluted with $8 \mathrm{~mL}$ of distilled water and stored at $-20^{\circ} \mathrm{C}$ for later determination of urea- $\mathrm{N}$ and purine derivatives. Feces were collected into large steel trays that were positioned over the gutter behind each stall. Daily fecal output for each cow was determined by weighing and feces were then mixed thoroughly before $2.5 \%$ of daily output was sampled and stored at $-20^{\circ} \mathrm{C}$ for later chemical analysis. During each 4-d total collection period, TMR and orts samples were collected daily and stored at $-20^{\circ} \mathrm{C}$ for later analysis.

To determine ruminal fermentation characteristics, approximately $1,000 \mathrm{~mL}$ of ruminal contents was collected from the cranial ventral, caudal ventral, central, and cranial dorsal rumen through the cannula at 0800 , $0900,1000,1100,1200,1500,1800$, and $2100 \mathrm{~h}$ on $\mathrm{d}$ 27 , and at 0000,0300 and $0600 \mathrm{~h}$ on $\mathrm{d} 28$. The ruminal contents were strained through 4 layers of cheesecloth. Ruminal fluid $\mathrm{pH}$ was then measured immediately using a model 265A portable $\mathrm{pH}$ meter (Orion Research Inc., Beverly, MA). Two 10-mL subsamples of ruminal fluid were collected and mixed with chilled $25 \%$ (wt/ vol) meta-phosphoric acid $\left(\mathrm{H}_{2} \mathrm{PO}_{4}\right)$ or $1 \% \mathrm{H}_{2} \mathrm{SO}_{4}$ and stored at $-20^{\circ} \mathrm{C}$ for later determination of $\mathrm{VFA}$ and $\mathrm{NH}_{3}$, respectively. Ruminal $\mathrm{pH}$ was also continuously measured every $30 \mathrm{~s}$ for 3 consecutive days starting on d 25 using the Lethbridge Research Centre Ruminal pH Measurement System (LRCpH; Dascor, Escondido, CA) as described by Penner et al. (2006).

During each measurement period, individual cow feed intake was recorded daily. Samples of TMR and orts were collected daily and stored at $-20^{\circ} \mathrm{C}$ for later analysis. Experimental cows were milked 3 times daily at 0430,1230 , and $1900 \mathrm{~h}$ and milk weights were recorded. At each milking on d 25 to 28 , milk was collected into plastic vials containing 2-bromo-2-nitropropane1-2-diol as a preservative. Daily milk samples from the 0430, 1230, and $1900 \mathrm{~h}$ milkings were then pooled proportionally based on milk yield from each milking, and pooled milk samples were stored at $4^{\circ} \mathrm{C}$ before being sent to the Provincial Milk Testing Laboratory (Saskatchewan Agriculture, Food and Rural Revitalization, Regina, SK, Canada) for compositional analysis. On d 28, blood samples were collected at $1030 \mathrm{~h}$ from the coccygeal vein of each cow into 10-mL Vacutainer tubes containing lithium heparin (Becton Dickinson, Franklin Lakes, NJ). Blood samples were centrifuged at 2,500 $\times$ $g$ for $15 \mathrm{~min}$ at $4^{\circ} \mathrm{C}$ and the plasma obtained was stored at $-20^{\circ} \mathrm{C}$ until later analysis for urea-nitrogen (PUN).

\section{Sample Analyses}

Pooled milk samples were analyzed for CP, lactose, and fat using an infrared analyzer (Foss System 4000, Foss Electric, Hillerød, Denmark; AOAC, 1990; method 972.16). After the experiment, frozen TMR and fecal samples were thawed overnight at room temperature, pooled per collection period for each cow, and subse- 
quently dried in an oven at $60^{\circ} \mathrm{C}$ for $48 \mathrm{~h}$ (AOAC, 1990; method 930.15). Dried TMR and fecal samples were then ground through a 1-mm screen using a ChristyNorris mill (Christy and Norris Ltd., Chelmsford, UK). Samples were analyzed for DM (AOAC, 1990; method 930.15), OM (AOAC, 1990; method 942.05), CP using the macro-Kjeldahl procedure (AOAC, 1990; method 976.05), ether extract (AOAC, 1990; method 920.39), and ADF and NDF (Van Soest et al., 1991). Amylase and sodium sulfite were used for NDF determination. Frozen urine samples were thawed overnight at room temperature and then analyzed for $\mathrm{N}$ using the macroKjeldahl procedure (AOAC, 1990; method 976.05). The plasma and dilute urine samples were analyzed for urea$\mathrm{N}$ by the diacetyl monoxime-based method of Marsh et al. (1957) using a colorimetric urea-N kit (Stanbio Urea Nitrogen Kit, Procedure No. 0580; Stanbio Laboratory, Boerne, TX).

The ${ }^{15} \mathrm{NB}$ samples were freeze-dried and ground through a 1-mm screen (Christy-Norris Ltd.) before being pulverized with a ball mill for later NAN and ${ }^{15} \mathrm{~N}$ analyses. The FAB and PAB pellets were freeze-dried and then ground with a mortar and pestle, after which composite samples of $\mathrm{FAB}$ and $\mathrm{PAB}$ were prepared for each cow per period by combining equal amounts (DM basis) from each sampling time. The 2.4-L omasal digesta composite samples were thawed at room temperature and fractionated into the 3 phases (i.e., LP, SP and FP) as described by Brito et al. (2009). Briefly, omasal digesta were squeezed through a single layer of cheesecloth. Solids retained on the cheesecloth were the LP. The filtrate was then centrifuged at 1,000 $\times g$ for $5 \mathrm{~min}$ at $5^{\circ} \mathrm{C}$, and the resultant pellet was the $\mathrm{SP}$ and the supernatant was the FP. The LP, SP, and FP samples were freeze-dried and then ground through a 1-mm screen (Christy-Norris mill) before $\mathrm{Yb}, \mathrm{Cr}$, and iNDF analysis. To determine $\mathrm{Cr}$ and $\mathrm{Yb}$ concentrations, a 1-g sample of each of the 3 phases (LP, SP, and FP) was combusted at $550^{\circ} \mathrm{C}$ for $8 \mathrm{~h}$ in a muffle furnace (AOAC, 1990) before nitric acid digestion as described by Vicente et al. (2004). Subsequently, Cr concentration was measured by atomic absorption spectrophotometry (Perkin Elmer 2300, Perkin-Elmer Corp., Norwalk, CT), whereas Yb concentration was quantified by atomic emission spectroscopy (Varian Spectra 220, Varian, Mulgrave, Australia). Indigestible NDF concentration was determined in duplicate TMR and LP samples, and in triplicate SP samples according to Ahvenjärvi et al. (2000). Briefly, 1.5-, 3.0-, and 3.5 -g samples of LP, TMR, and SP, respectively, were weighed into $5-\times 10-\mathrm{cm}$ nylon mesh bags $(6-\mu \mathrm{m}$ pore size; part no. 03-6/5, Sefar America Inc., Depew, NY) before incubation for $12 \mathrm{~d}$ in the rumen of a ruminally cannulated cow. Following incubation, bags were rinsed in water for 30 min before NDF analysis. The mean concentration of $\mathrm{Cr}$ was 7.7 and 15.4 times greater in FP than in SP and LP, respectively, whereas the $\mathrm{Yb}$ concentration was 2.5 and 2.9 times greater in SP than in FP and LP, respectively. The mean iNDF concentration was 6.3 times greater in LP than in SP. As a result of the concentrations of the 3 principal markers being distinctly greater in their respective digesta phases, the $\mathrm{Cr}, \mathrm{Yb}$, and iNDF concentrations in LP and $\mathrm{SP}$, and $\mathrm{Cr}$ and $\mathrm{Yb}$ concentrations in $\mathrm{FP}$ were used to physically reconstitute the omasal true digesta (OTD) flowing out of the rumen using the triple-marker method of France and Siddons (1986). Marker concentrations were also used to physically reconstitute a 2 -g particle phase (PF) sample consisting of SP and LP.

To determine the flow of nutrients to the omasum, the OTD samples were analyzed for OM by combustion in a muffle furnace at $550^{\circ} \mathrm{C}$ for at $8 \mathrm{~h}$, total $\mathrm{N}$ (Leco 2000; Leco Instruments Inc., St. Joseph, MI), ADF, and NDF. To quantify $\mathrm{NH}_{3}-\mathrm{N}$ in OTD, $10 \mathrm{~mL}$ of 0.07 $M$ sodium citrate ( $\mathrm{pH} 2.2$ ) was added to $0.5 \mathrm{~g}$ of OTD sample and the mixture vortexed and subsequently held at $39^{\circ} \mathrm{C}$ for $30 \mathrm{~min}$ in a forced-air oven. The extracts were then centrifuged at $18,000 \times g$ for $15 \mathrm{~min}$ at $4^{\circ} \mathrm{C}$, and the resultant supernatant was analyzed for $\mathrm{NH}_{3^{-}}$ $\mathrm{N}$ using the phenol-hypochlorite method as described by Broderick and Kang (1980). Samples of ${ }^{15} \mathrm{NB}$, FAB, $\mathrm{PAB}, \mathrm{FP}, \mathrm{PF}$, and OTD were prepared for ${ }^{15} \mathrm{~N}$ analysis as described by Brito et al. (2009). Briefly, to volatize $\mathrm{NH}_{3}-\mathrm{N}$ before ${ }^{15} \mathrm{~N}$ analysis, ${ }^{15} \mathrm{NB}, \mathrm{FAB}, \mathrm{PAB}, \mathrm{FP}$, $\mathrm{PF}$, and OTD samples containing approximately 100 $\mu \mathrm{g}$ of $\mathrm{N}$ were weighed into $5-\times 9-\mathrm{mm}$ tin capsules (Elemental Microanalysis Limited, Okehampton, UK). Subsequently, $50 \mu \mathrm{L}$ of $72 \mathrm{mM} \mathrm{K} \mathrm{K}_{2} \mathrm{CO}_{3}$ was added to each capsule before incubation in a forced air oven at $60^{\circ} \mathrm{C}$ for $24 \mathrm{~h}$. Enrichment of ${ }^{15} \mathrm{~N}$ in NAN of the samples was then measured by combustion to $\mathrm{N}_{2}$ gas in an elemental analyzer and continuous flow isotope ratio-mass spectrometry.

For AA analysis, TMR and OTD samples were prepared by acid hydrolysis (AOAC, 1995; method 994.12) to liberate individual AA from proteins. Briefly, approximately $100 \mathrm{mg}$ of TMR or OTD sample was weighed and then hydrolyzed under reflux in $6 \mathrm{M}$ $\mathrm{HCl}$ at $110^{\circ} \mathrm{C}$ for $24 \mathrm{~h}$. Hydrolyzed samples were then neutralized with $25 \%$ (wt/vol) $\mathrm{NaOH}$ and cooled to room temperature, and then the neutralized samples were then diluted to $50 \mathrm{~mL}$ total volume using sodium citrate buffer ( $\mathrm{pH} 2.2$ ). The separation and quantification of individual AA in hydrolyzed samples were performed using HPLC (Shimadzu, Columbia, MD). For the determination of cysteine and methionine in TMR and OTD samples, performic acid oxidation was performed before acid hydrolysis to oxidize cysteine and 
methionine to cysteic acid and methionine sulfone, respectively (AOAC, 1995; method 994.12). Tryptophan was determined after hydrolysis of $100 \mathrm{mg}$ of sample with $5 \mathrm{M} \mathrm{NaOH}$ at $120^{\circ} \mathrm{C}$ for $16 \mathrm{~h}$ using the method of Hugli and Moore (1972).

Frozen ruminal fluid samples were thawed at room temperature and centrifuged at 20,000 $\times g$ for $15 \mathrm{~min}$ at $4^{\circ} \mathrm{C}$ to obtain a clear supernatant. For ruminal fluid samples that were preserved with $25 \% \mathrm{H}_{2} \mathrm{PO}_{4}$, supernatants were filtered through a $0.45-\mu \mathrm{m}$ membrane, and a $0.9-\mathrm{mL}$ portion of the filtered supernatant was mixed with $0.1 \mathrm{~mL}$ of $10 \mathrm{mg} / \mathrm{mL}$ crotonic acid as an internal standard. Ruminal VFA were separated and quantified by GC (Agilent 6890, Mississauga, ON, Canada) as described by Erwin et al. (1961). For ruminal fluid samples that were preserved with $\mathrm{H}_{2} \mathrm{SO}_{4}$, supernatants were analyzed for ruminal $\mathrm{NH}_{3}-\mathrm{N}$ using a phenol-hypochlorite assay (Broderick and Kang, 1980).

\section{Calculations and Statistical Analysis}

The ruminal $\mathrm{pH}$ data that were recorded daily were averaged for each minute and summarized daily as minimum, mean, and maximum $\mathrm{pH}$. The degree and incidence of ruminal acidosis was determined from the $\mathrm{pH}$ data using $3 \mathrm{pH}$ thresholds: 5.8, 5.5, and 5.2. Ruminal acidosis was considered to occur when ruminal $\mathrm{pH}$ was $<5.8$ (total ruminal acidosis). The $\mathrm{pH}$ profiles were further classified as mild RA when $5.8>$ ruminal $\mathrm{pH}$ $>5.5$, severe RA when $5.5>$ ruminal $\mathrm{pH}>5.2$, and acute RA when ruminal $\mathrm{pH}<5.2$ (Penner et al., 2006). The duration $(\mathrm{min} / \mathrm{d})$ and total area $(\mathrm{pH} \times \min )$ that ruminal $\mathrm{pH}$ was below each threshold was calculated.

The flow of nutrients at the omasal canal was calculated as described by Brito et al. (2009) with minor modifications. Omasal flow of NAN, assumed to consist of PAB NAN, LAB NAN, and non- $\mathrm{NH}_{3}$ nonbacterial $\mathrm{N}$ (NANBN), was calculated as the difference between total omasal $\mathrm{N}$ and $\mathrm{NH}_{3}-\mathrm{N}$ flow. The natural abundance of the 16 background ${ }^{15} \mathrm{~N}$ digesta samples averaged $0.36809 \pm 0.00012(\mathrm{SD})$. In a study by Ahvenjärvi et al. (2002), the background ${ }^{15} \mathrm{~N}$ enrichment in bacteria was similar to that of the digesta. Based on those observations, ${ }^{15} \mathrm{~N}$ enrichment in bacterial and omasal fractions in the current study was computed using ${ }^{15} \mathrm{NB}$ as ${ }^{15} \mathrm{~N}$ enrichment $\left({ }^{15} \mathrm{~N}\right.$ APE $)={ }^{15} \mathrm{~N}$ atom $\%-0.36809$ (background ${ }^{15} \mathrm{~N}$ atom \%). Following the assumptions that FAB was representative of bacteria flowing with $\mathrm{FP}$, whereas $\mathrm{PAB}$ was representative of bacteria flowing with PF, omasal flows of FAB NAN, PAB NAN, total bacterial NAN, NANBN, RDP supply, and OM truly digested in the rumen (OMTDR) were computed as follows: FAB NAN flow $=\mathrm{FP}$ NAN flow $\times\left(\mathrm{FP}{ }^{15} \mathrm{~N}\right.$ $\mathrm{APE} \div \mathrm{FAB}{ }^{15} \mathrm{~N}$ APE); $\mathrm{PAB}$ NAN flow $=\mathrm{PF}$ NAN flow $\times\left(\mathrm{PF}{ }^{15} \mathrm{~N}\right.$ APE $\div$ PAB ${ }^{15} \mathrm{~N}$ APE $)$; total bacterial NAN flow $=$ FAB NAN flow + PAB NAN flow; NANMN flow $=$ total NAN flow - total bacterial NAN flow; RDP supply $=$ total CP intake $-($ NANBN flow $\times 6.25)$; FAB DM flow $=$ FAB NAN flow $\div(\%$ FAB NAN $\div 100)$; PAB DM flow $=$ PAB NAN flow $\div(\%$ PAB NAN $\div 100)$; FAB OM flow $=($ FAB DM flow $\times$ $\%$ FAB OM $) \div 100 ;$ PAB OM flow $=($ PAB DM flow $\times \%$ PAB OM $) \div 100$; and total bacterial OM flow $=$ FAB OM flow + PAB OM flow. Flows and intakes are in grams or kilograms per day and NAN concentrations are in grams per gram of OM.

All data on ruminal fermentation parameters, nutrient digestibilities, omasal flow, and excretion were analyzed as a $4 \times 4$ Latin square using the MIXED procedure of SAS (SAS Institute, 2002) according to the following model: $Y_{i j k}=\mu+P_{i}+C_{j}+T_{k}+E_{i j k}$, where $Y_{i j k}$ is the dependent variable, $\mu$ is the overall mean, $\mathrm{P}_{\mathrm{i}}$ is the fixed effect of period $\mathrm{i}, \mathrm{C}_{\mathrm{j}}$ is the random effect of cow $\mathrm{j}, \mathrm{T}_{\mathrm{k}}$ is the fixed effect of dietary treatment $\mathrm{k}$, and $\mathrm{E}_{\mathrm{ijk}}$ is the residual error. Ruminal $\mathrm{pH}$, VFA, and $\mathrm{NH}_{3}-\mathrm{N}$ data were analyzed accounting for repeated measures through the inclusion of the variable time in the repeated statement, as well as terms for time (hour), and interaction (diet $\times$ time) in the model described previously. Production data for the 8 cows were analyzed using the MIXED procedure of SAS (SAS Institute, 2002) for a replicated $4 \times 4$ Latin square design according to the following model: $\mathrm{Y}_{\mathrm{ijkl}}=$ $\mu+S_{i}+P_{j}+C_{k(i)}+T_{1}+S_{i l}+E_{i j k l}$, where $Y_{i j k l}$ is the dependent variable, $\mu$ is the overall mean, $S_{i}$ is the fixed effect of square $\mathrm{i}, \mathrm{P}_{\mathrm{j}}$ is the fixed effect of period $\mathrm{j}, \mathrm{C}_{\mathrm{k}(\mathrm{i})}$ is the random effect of cow $\mathrm{k}$ (within square $\mathrm{i}$ ), $\mathrm{T}_{1}$ is the fixed effect of dietary treatment $1, \mathrm{ST}_{\mathrm{il}}$ is the interaction between square $\mathrm{i}$ and treatment 1 , and $\mathrm{E}_{\mathrm{ijkl}}$ is the residual error. The interaction term was removed from the model when $P>0.25$. Orthogonal contrasts were used to test for linear and quadratic effects of level of W-DDGS in the diet. Significance was declared at $P \leq 0.05$ and trends at $0.05<P \leq 0.10$. All reported values are least squares means, which were separated using the PDIFF test in SAS.

\section{RESULTS}

\section{Diet Composition}

Dietary ingredient and chemical composition are presented in Table 1. Because W-DDGS had a higher CP content than CM, W-DGGS replaced all CM and varying proportions of soybean meal in the concentrate portion of diets containing W-DDGS to make all diets isonitrogenous. Diets were also formulated to be isoenergetic. Dietary contents of RDP and RUP that were calculated from observed omasal flows of NAN 
Table 2. Amino acid composition (\% of DM) of TMR containing dried distillers grains with solubles (DDGS)

\begin{tabular}{|c|c|c|c|c|}
\hline \multirow[b]{2}{*}{ Item } & \multicolumn{4}{|c|}{ Diet } \\
\hline & Control & $10 \%$ DDGS & $15 \%$ DDGS & $20 \%$ DDGS \\
\hline \multicolumn{5}{|l|}{ Essential AA } \\
\hline Arginine & 0.853 & 0.686 & 0.636 & 0.628 \\
\hline Histidine & 0.397 & 0.349 & 0.315 & 0.333 \\
\hline Isoleucine & 0.780 & 0.709 & 0.658 & 0.733 \\
\hline Leucine & 1.350 & 1.265 & 1.191 & 1.223 \\
\hline Lysine & 0.926 & 0.702 & 0.642 & 0.593 \\
\hline Methionine & 0.293 & 0.290 & 0.285 & 0.294 \\
\hline Phenylalanine & 0.793 & 0.746 & 0.780 & 0.760 \\
\hline Threonine & 0.671 & 0.609 & 0.608 & 0.602 \\
\hline Tryptophan & 0.195 & 0.201 & 0.192 & 0.174 \\
\hline Valine & 0.898 & 0.779 & 0.762 & 0.817 \\
\hline \multicolumn{5}{|l|}{ Nonessential AA } \\
\hline Alanine & 0.995 & 0.947 & 0.906 & 0.943 \\
\hline Asparagine & 1.491 & 1.332 & 1.193 & 1.148 \\
\hline Cysteine & 0.283 & 0.275 & 0.274 & 0.292 \\
\hline Glutamine & 3.284 & 3.489 & 3.505 & 4.014 \\
\hline Glycine & 0.798 & 0.703 & 0.704 & 0.742 \\
\hline Proline & 1.431 & 1.392 & 1.510 & 1.605 \\
\hline Serine & 0.689 & 0.686 & 0.668 & 0.686 \\
\hline Tyrosine & 0.434 & 0.422 & 0.388 & 0.429 \\
\hline
\end{tabular}

fractions and DM intakes ranged from 11 to $12.7 \%$, and from 6.64 to $7.52 \%$ (\% of DM), respectively. The AA composition of TMR is presented in Table 2. Notably, lysine content decreased with increasing amounts of W-DDGS in TMR, reflecting the low concentration of lysine in W-DDGS.

\section{Feed Intake and Milk Production}

Results on feed intake and milk production presented in Table 3 are from all 8 cows that were used in the study. The inclusion of W-DDGS resulted in a linear increase in $\mathrm{DM}(P<0.01)$ and $\mathrm{CP}(P=0.02)$ intake (Table 3). A tendency $(P=0.05)$ was observed for a linear increase in milk production with W-DDGS; however, there was no diet effect $(P=0.35)$ on ECM. Quadratic changes were observed in apparent DM efficiency (ECM/DMI; $P<0.01$ ) and N efficiency (milk $\mathrm{N} / \mathrm{N}$ intake; $P<0.01$ ) with increasing $\mathrm{W}-\mathrm{DDGS}$ in the diet. Milk fat, protein, and lactose contents were not different $(P>0.05)$ among diets; however, the inclusion of W-DDGS resulted in quadratic changes $(P \leq$ 0.03 ) in milk fat, protein, and lactose yields. Feeding increasing amounts of W-DDGS tended to increase $(P$ $=0.10)$ PUN concentration, which averaged $21.4 \mathrm{mg} /$ $\mathrm{dL}$ for the diets containing W-DDGS compared with $20.3 \mathrm{mg} / \mathrm{dL}$ for the control diet (Table 3).

\section{Ruminal Fermentation Characteristics}

The daily mean, minimum, and maximum ruminal $\mathrm{pH}$, and degree of subacute ruminal acidosis (duration and area below the $\mathrm{pH}$ thresholds of 5.5 and 5.8) were similar across diets (Table 4). Ruminal VFA concentrations were unaffected by diet, except that the inclusion of $20 \% \mathrm{~W}$-DDGS resulted in a decrease $(P<0.01)$ and a tendency $(P=0.09)$ for a decrease in the molar concentrations of isobutyrate and total VFA, respectively (Table 4). Ruminal $\mathrm{NH}_{3}-\mathrm{N}$ concentrations were unaffected $(P=0.89)$ by diet. Because ruminal fermentation characteristics were measured at various time points relative to feeding, a time $\times$ treatment interaction for any of the ruminal variables that were measured would be indicative of differences in fermentation patterns; however, no treatment $\times$ time interactions were found for ruminal ammonia and VFA concentrations, which indicates that fermentation patterns were essentially similar across diets (Table 4).

\section{Nutrient Intakes, Ruminal Digestibilities, and Omasal Nutrient Flows}

Intake, omasal flow, amount digested in the rumen, and apparent ruminal digestibility of DM were not affected $(P>0.05)$ by dietary treatment (Table 5$)$. Organic matter intake was similar $(P=0.76)$ across diets and averaged $29.2 \mathrm{~kg} / \mathrm{d}$. Dietary inclusion of W-DDGS resulted in a linear decrease $(P=0.01)$ in the amount of OM apparently digested in the rumen and a tendency for a linear increase $(P=0.09)$ in the amount of OM flowing at the omasal canal. However, the percentage of OM apparently digested in the rumen was not affected by diet. Although the amount of OM truly digested in the rumen was not different, a 
Table 3. Dry matter and CP intakes, milk yield and composition, and plasma urea-N (PUN) of dairy cows fed increasing amounts of wheatbased dried distillers grains with solubles (DDGS) ${ }^{1}$

\begin{tabular}{|c|c|c|c|c|c|c|c|c|}
\hline \multirow[b]{2}{*}{ Item } & \multicolumn{4}{|c|}{ Diet } & \multirow[b]{2}{*}{ SEM } & \multicolumn{3}{|c|}{$P$-value ${ }^{2}$} \\
\hline & Control & $10 \%$ DDGS & $15 \%$ DDGS & $20 \%$ DDGS & & Diet & Linear & Quadratic \\
\hline $\mathrm{CP}$ intake, $\mathrm{kg} / \mathrm{d}$ & 5.62 & 5.73 & 5.86 & 5.87 & 0.405 & 0.09 & 0.02 & 0.48 \\
\hline Milk yield, $\mathrm{kg} / \mathrm{d}$ & $42.9^{\mathrm{b}}$ & $44.7^{\mathrm{a}}$ & $44.1^{\mathrm{ab}}$ & $44.5^{\mathrm{a}}$ & 2.31 & 0.04 & 0.05 & 0.14 \\
\hline $\mathrm{ECM}^{3}{ }^{3} \mathrm{~kg} / \mathrm{d}$ & 45.0 & 45.0 & 44.5 & 45.4 & 1.83 & 0.35 & 0.79 & 0.11 \\
\hline Feed efficiency ${ }^{4}$ & $1.47^{\mathrm{ab}}$ & $1.49^{\mathrm{a}}$ & $1.50^{\mathrm{a}}$ & $1.44^{\mathrm{b}}$ & 0.033 & $<0.01$ & 0.15 & $<0.01$ \\
\hline Milk fat yield, $\mathrm{kg} / \mathrm{d}$ & $1.48^{\mathrm{b}}$ & $1.56^{\mathrm{ab}}$ & $1.62^{\mathrm{a}}$ & $1.55^{\mathrm{ab}}$ & 0.061 & 0.03 & 0.05 & 0.03 \\
\hline Milk protein, $\%$ & 3.32 & 3.29 & 3.30 & 3.30 & 0.065 & 0.54 & 0.33 & 0.30 \\
\hline Milk protein yield, $\mathrm{kg} / \mathrm{d}$ & $1.44^{\mathrm{bc}}$ & $1.46^{\mathrm{ab}}$ & $1.49^{\mathrm{a}}$ & $1.42^{\mathrm{c}}$ & 0.043 & 0.03 & 0.64 & $<0.01$ \\
\hline Milk lactose, \% & 4.54 & 4.52 & 4.57 & 4.55 & 0.034 & 0.28 & 0.50 & 0.93 \\
\hline Milk lactose yield, $\mathrm{kg} / \mathrm{d}$ & $1.96^{\mathrm{c}}$ & $2.02^{\mathrm{b}}$ & $2.09^{\mathrm{a}}$ & $1.93^{\mathrm{d}}$ & 0.035 & $<0.01$ & 0.14 & $<0.01$ \\
\hline PUN, mg/dL & 20.3 & 21.7 & 21.0 & 21.4 & 0.82 & 0.10 & 0.12 & 0.05 \\
\hline
\end{tabular}

${ }^{\mathrm{a}-\mathrm{d}}$ Means within a row with different superscripts differ $(P<0.05)$.

${ }^{1}$ Values are least squares means obtained from 8 cows.

${ }^{2} P$-values indicate overall diet, linear, and quadratic effects.

${ }^{3}$ Calculated as $[0.327 \times$ milk yield $(\mathrm{kg})]+[12.95 \times$ fat yield $(\mathrm{kg})]+[7.2 \times$ protein yield $(\mathrm{kg})]($ Orth, 1992).

${ }^{4}$ Feed efficiency $=$ ECM/DMI

${ }^{5}$ Nitrogen efficiency $=$ milk $\mathrm{N}(\mathrm{kg} / \mathrm{d}) / \mathrm{N}$ intake $(\mathrm{kg} / \mathrm{d})$.

tendency was observed for a decrease $(P=0.08)$ in the percentage of OMTDR with the inclusion of W-DDGS. Quadratic changes $(P<0.01)$ in NDF and ADF intakes were observed when W-DDGS was added to the diets; however, omasal flows and amounts and percentages of $\mathrm{NDF}$ and ADF apparently digested in the rumen were not different across diets (Table 5).

\section{Omasal Flow of Nitrogen Fractions and AA, and Microbial Protein Synthesis}

Intake of $\mathrm{N}$ was unaffected by $\operatorname{diet}(P=0.24)$ and averaged $934 \mathrm{~g} / \mathrm{d}$ (Table 6). Similarly, N apparently digested in the rumen, when expressed as grams per day $(P=0.62)$ or as a proportion of $\mathrm{N}$ intake $(P=$

Table 4. Ruminal fermentation characteristics of dairy cows fed increasing amounts of wheat-based dried distillers grains with solubles (DDGS) ${ }^{1}$

\begin{tabular}{|c|c|c|c|c|c|c|c|c|}
\hline \multirow[b]{2}{*}{ Item } & \multicolumn{4}{|c|}{ Diet } & \multirow[b]{2}{*}{ SEM } & \multicolumn{3}{|c|}{$P$-value ${ }^{2}$} \\
\hline & Control & $10 \%$ DDGS & $15 \%$ DDGS & $20 \%$ DDGS & & Diet & Linear & Quadratic \\
\hline Mean & 6.04 & 6.08 & 6.02 & 6.13 & 0.15 & 0.14 & 0.18 & 0.28 \\
\hline Minimum & 5.53 & 5.55 & 5.50 & 5.60 & 0.18 & 0.23 & 0.29 & 0.24 \\
\hline Maximum & 6.68 & 6.71 & 6.67 & 6.77 & 0.12 & 0.25 & 0.22 & 0.33 \\
\hline \multicolumn{9}{|l|}{ Duration, $\min / \mathrm{d}$} \\
\hline \multicolumn{9}{|l|}{ Area, $\mathrm{pH} \times \min / \mathrm{d}$} \\
\hline $\mathrm{pH}<5.8$ & 82.1 & 73.8 & 98.8 & 84.6 & 47.43 & 0.87 & 0.74 & 0.89 \\
\hline $\mathrm{pH}<5.5$ & 10.2 & 13.5 & 16.5 & 21.0 & 10.42 & 0.79 & 0.33 & 0.94 \\
\hline \multicolumn{9}{|l|}{ Ruminal VFA, ${ }^{3} \mathrm{~m} M$} \\
\hline Acetate & 100.9 & 100.8 & 101.5 & 94.5 & 4.08 & 0.61 & 0.36 & 0.43 \\
\hline Propionate & 26.0 & 25.8 & 28.2 & 26.4 & 2.36 & 0.62 & 0.56 & 0.59 \\
\hline Butyrate & 14.8 & 15.6 & 15.0 & 13.9 & 1.16 & 0.49 & 0.38 & 0.24 \\
\hline Ruminal $\mathrm{NH}_{3}-\mathrm{N},{ }^{3} \mathrm{mg} / \mathrm{dL}$ & 16.7 & 16.5 & 17.0 & 16.3 & 1.31 & 0.75 & 0.69 & 0.61 \\
\hline
\end{tabular}

${ }^{\mathrm{a}, \mathrm{b}}$ Means within a row with different superscripts differ $(P<0.05)$.

${ }^{1}$ Values are least squares means obtained from 4 ruminally cannulated cows.

${ }^{2} P$-values indicate overall diet, time, and diet $\times$ time effects.

${ }^{3}$ There were significant effects of sampling time on ruminal concentrations of $\mathrm{NH}_{3}-\mathrm{N}$, and total and individual VFA, and acetate:propionate ratio $(P<0.01)$. Diet $\times$ time of sampling interactions were not significant. 
Table 5. Nutrient flow from and digestion in the rumen of dairy cows fed increasing amounts of wheat-based dried distillers grains with solubles $(\mathrm{DDGS})^{1}$

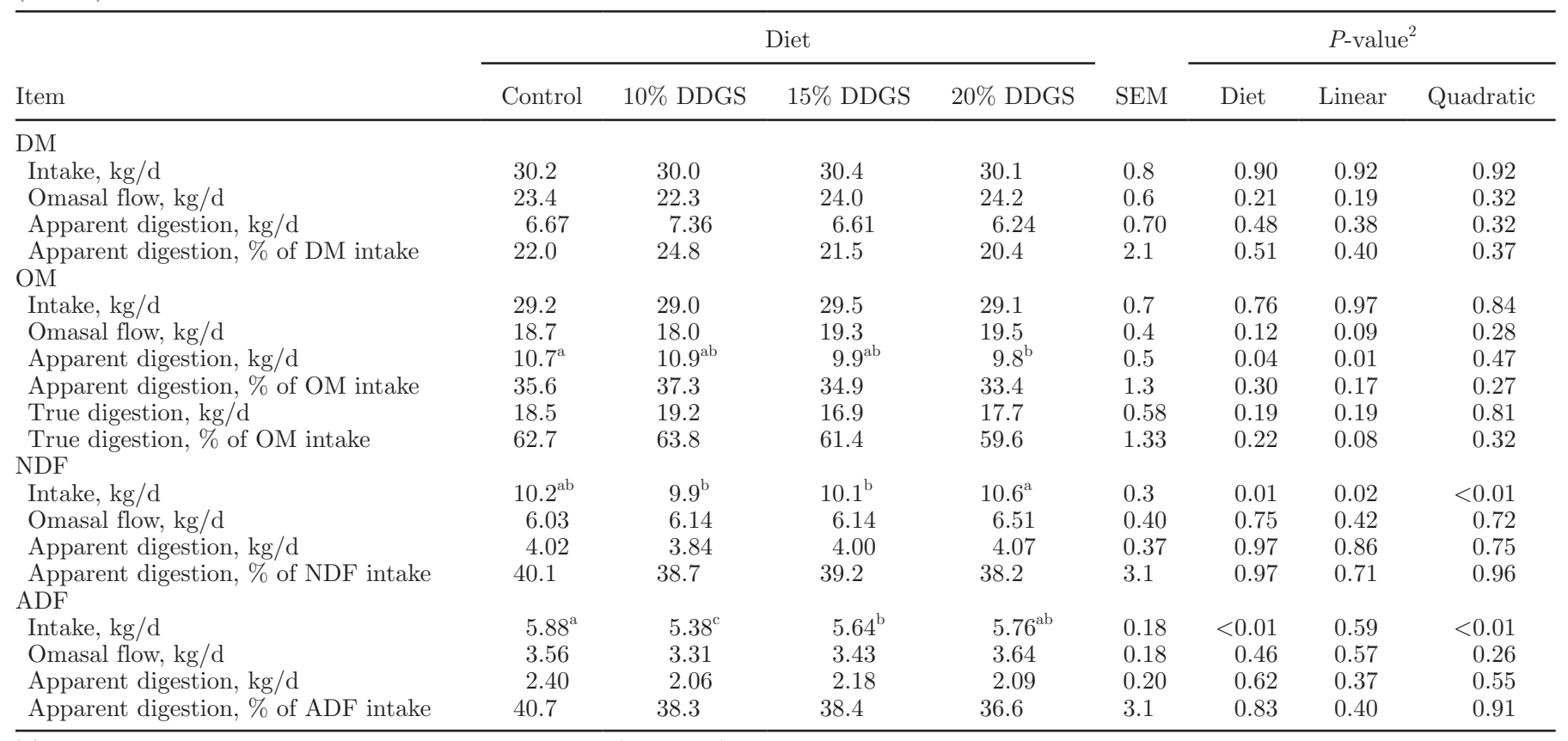

${ }^{\mathrm{a}-\mathrm{c}}$ Means within a row with different superscripts differ $(P<0.05)$.

${ }^{1}$ Values are least squares means obtained from 4 ruminally cannulated cows.

${ }^{2} P$-values indicate overall diet, linear, and quadratic effects.

0.22), did not differ across diets. Although N truly digested in the rumen expressed as grams per day was similar $(P=0.21)$ across treatments, $\mathrm{N}$ truly digested in the rumen expressed as a proportion of $\mathrm{N}$ intake decreased linearly $(P=0.02)$ with increasing amounts of $\mathrm{W}$-DDGS in the diet. Increasing the level of W-DDGS in the diet resulted in a tendency for a linear decrease $(P=0.09)$ in RDP supply when expressed as grams per day, and a linear decrease $(P=0.02)$ in RDP supply when expressed as a proportion of DM intake. The omasal flow of total $\mathrm{N}$ expressed as grams per day or as a proportion of $\mathrm{N}$ intake did not differ $(P=0.14)$ with dietary treatment. Ammonia $\mathrm{N}$ flowing at the omasum was similar $(P=0.24)$ across diets. Omasal flow of NAN expressed as grams per day tended to increase linearly $(P=0.09)$ with dietary inclusion of W-DDGS. A quadratic increase $(P<0.01)$ was observed in the flow of NANBN at the omasum, expressed as grams per day and as a proportion of omasal NAN flow, whereas omasal NANBN flow expressed as a proportion of DM $(P=0.05)$ or $\mathrm{N}(P=0.03)$ intakes increased linearly with the inclusion of W-DDGS in the diet. The supply of RUP when expressed as grams per day increased linearly $(P=0.01)$ with the addition of W-DDGS to the diet; however, diet had no effect $(P=0.28)$ on RUP supply when expressed as a proportion of DM intake. Omasal flows of FAB NAN and PAB NAN when ex- pressed as grams per day were similar $(P>0.05)$ across diets and, thus, the omasal flow of total bacterial NAN (i.e., FAB NAN plus PAB NAN) was not different $(P$ $=0.31)$. However, a quadratic response $(P<0.01)$ was found for the omasal flow of total bacterial NAN when expressed as a proportion of total NAN flow. Efficiency of microbial protein synthesis did not differ $(P=0.12)$ among diets.

Omasal flow of all essential amino acids (EAA) did not differ $(P>0.05)$ among diets (Table 7). However, a linear decrease $(P=0.02)$ from 17.0 to $15.9 \%$ was observed in the omasal flow of lysine, when expressed as a proportion of total EAA, with increasing levels of $\mathrm{W}$ DGGS in the diet, whereas omasal flow of methionine, when expressed as a proportion of total EAA, did not change, averaging $5.19 \%$. Consequently, the inclusion of W-DDGS in the diet had a quadratic effect $(P=$ 0.04 ) on the lysine:methionine ratio in omasal digesta. The addition of W-DDGS to the diet resulted in a linear increase $(P \leq 0.02)$ in the omasal flow of cysteine, glutamate, and proline, whereas the flow of the other NEAA did not differ $(P>0.05)$.

\section{Excretion and Total-Tract Digestibility of Nutrients}

Total urinary $\mathrm{N}$ excretion did not differ when expressed as grams per day $(P=0.78)$ or percentage of $\mathrm{N}$ 
Table 6. Intake, digestibility, and omasal flow of $\mathrm{N}$ constituents in dairy cows fed increasing amounts of wheat-based dried distillers grains with solubles (DDGS) ${ }^{1}$

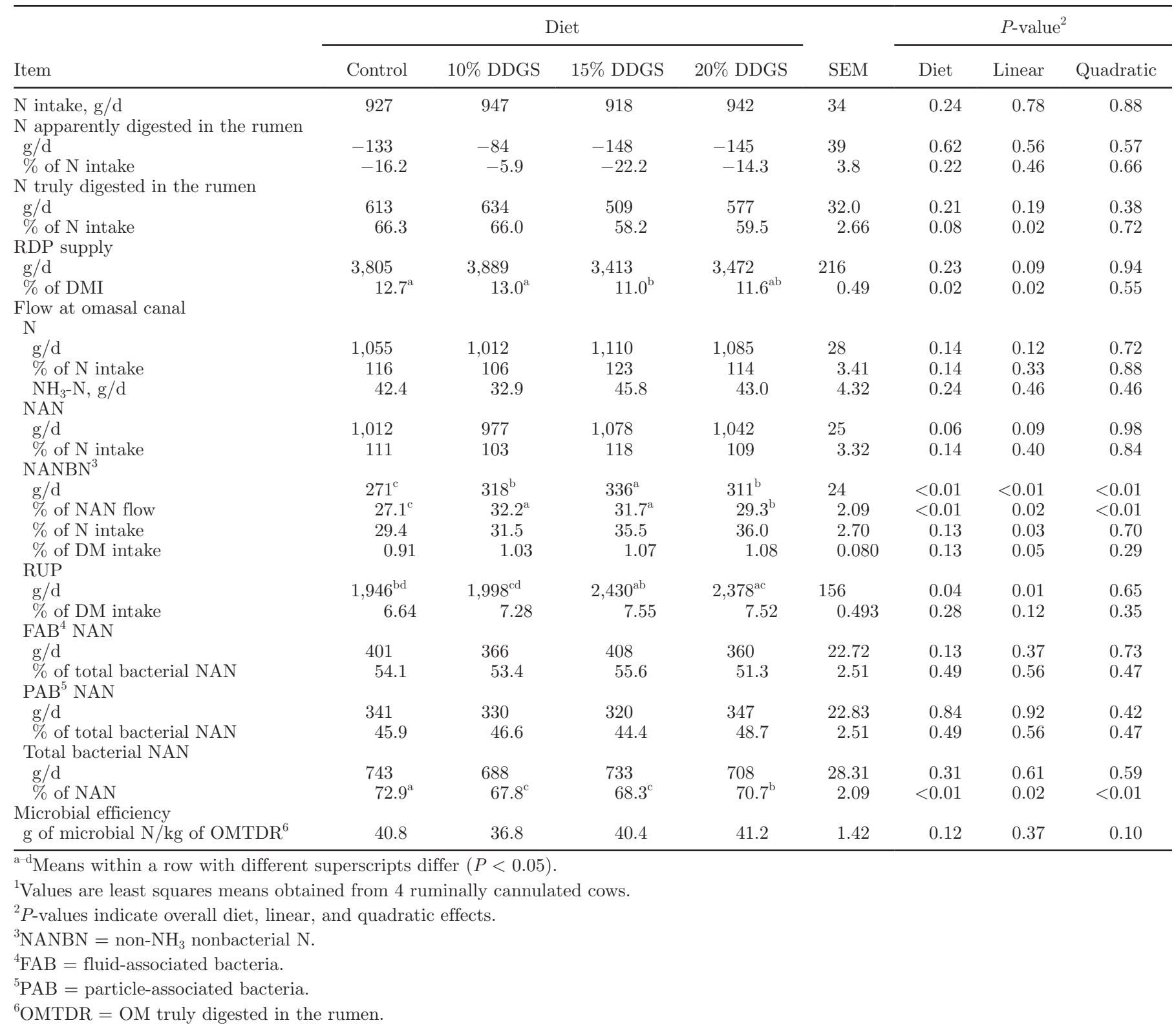

intake $(P=0.36$; Table 8$)$. However, the dietary inclusion of W-DDGS had a quadratic $(P=0.01)$ effect on urinary urea- $\mathrm{N}$ excretion when expressed as grams per day, whereas urinary urea- $\mathrm{N}$ excretion when expressed as a percentage of urinary $\mathrm{N}$ was unaffected by diet. When fecal $\mathrm{N}$ excretion was expressed as grams per day, a tendency $(P=0.06)$ for a linear increase was observed with increasing levels of W-DDGS, but fecal $\mathrm{N}$ excretion expressed as a percentage of $\mathrm{N}$ intake was similar $(P=0.59)$ across diets. Total $\mathrm{N}$ excretion when expressed as grams per day was not different across diets $(P=0.14)$; however, a quadratic change $(P=$
$0.03)$ in total $\mathrm{N}$ excretion was observed when expressed as a percentage of $\mathrm{N}$ intake. Diets did not differ $(P>$ 0.05) in apparent total-tract digestibilities of DM, OM, $\mathrm{CP}, \mathrm{ADF}$, and NDF (Table 8).

\section{DISCUSSION}

The type, amount, and quality (e.g., true protein vs. NPN) of protein supplements that are included in a diet are key factors that can influence ruminal fermentation and the flow of microbial NAN and NANBN to the small intestine in dairy cows (Clark et al., 1992; 
Table 7. Omasal amino acid flow $(\mathrm{g} / \mathrm{d})$ in dairy cows fed increasing amounts of wheat-based dried distillers grains with solubles (DDGS) ${ }^{1}$

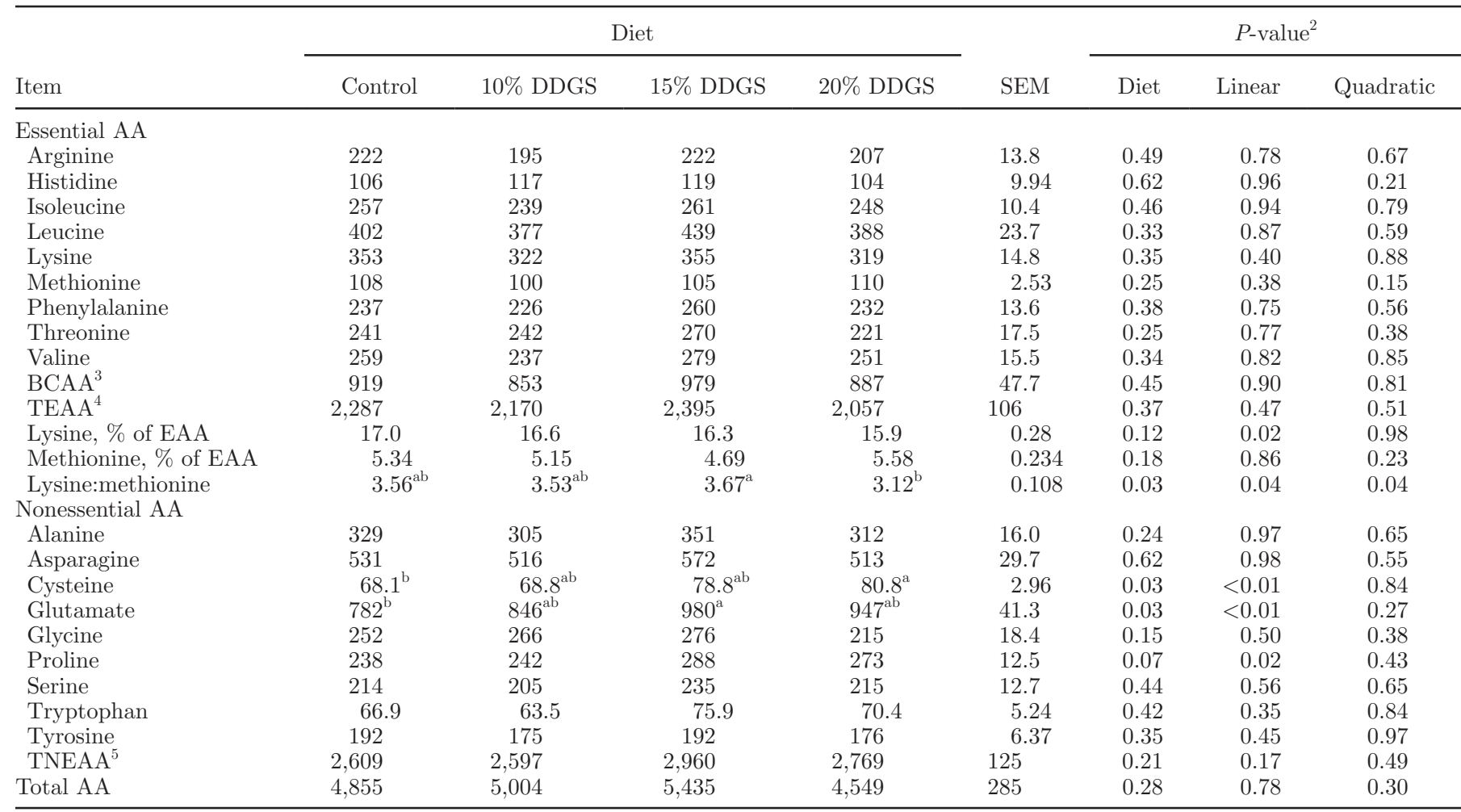

\footnotetext{
$\overline{\mathrm{a}, \mathrm{b}}$ Means within a row with different superscripts differ $(P<0.05)$.

${ }^{1}$ Values are least squares means obtained from 4 ruminally cannulated cows.

${ }^{2} P$-values indicate overall diet, linear, and quadratic effects.

${ }^{3} \mathrm{BCAA}=$ branched-chain $\mathrm{AA}$ (isoleucine + leucine + valine).

${ }^{4}$ TEAA $=$ total essential AA.

${ }^{5}$ TNEAA $=$ total nonessential AA.
}

Ipharraguerre and Clark, 2005). In western Canada and parts of the United States, dairy cow diets typically contain CM as the principal source of protein because it is readily available and is a high quality protein supplement (Hickling, 2008; Mulrooney et al., 2009). However, a rapid expansion of the ethanol industry in western Canada has resulted in large quantities of W-DDGS becoming available for feeding dairy cows. Major differences in the chemical compositions and ruminal degradabilities of CM and W-DDGS have been reported (Boila and Ingalls, 1994), so the major objective of the current study was to determine the effect of replacing $\mathrm{CM}$ as the major protein source with $\mathrm{W}$ DDGS on microbial protein synthesis and omasal flow of $\mathrm{N}$ fractions. In the current study, CM, which is primarily a RDP source with an excellent AA profile, was completely replaced with W-DDGS, which provides a greater proportion of RUP, in dairy diets that were formulated to be isonitrogenous. Therefore, differences between CM and W-DDGS in ruminal protein degradability and AA composition were expected to affect ruminal digestion and omasal flow of $\mathrm{N}$ fractions.
In the present study, we used the omasal sampling technique (Huhtanen et al., 1997) to collect omasal digesta. This procedure involved the insertion into the omasal canal, via the ruminal cannula, of a sampling tube that was connected to a compressor and vacuum pump for aspirating omasal digesta. Once the tube was inserted into the omasal canal, 12 spot samples of omasal digesta were then collected at 6 -h intervals over a 3-d collection period such that the sampling times were equally distributed over a 24-h feeding cycle to ensure representative sampling. Our observations of animal behavior indicated that omasal sampling had very minimal effects on the cows, and this is supported by the high DMI and high levels of milk production. Omasal digesta flow was determined using the triplemarker method (France and Siddons, 1986). Estimates of digesta flow at the omasum that are obtained using omasal sampling can be erroneous if marker dysfunction occurs (Huhtanen et al., 2010). In the present study, the mean concentration of $\mathrm{Cr}$ was 7.7 and 15.4 times greater in $\mathrm{FP}$ than in $\mathrm{SP}$ and $\mathrm{LP}$, respectively, whereas the $\mathrm{Yb}$ concentration was 2.5 and 2.9 times greater in 
Table 8. Urinary N excretion, fecal excretion, and apparent total-tract digestibilities in dairy cows fed increasing amounts of wheat-based dried distillers grains with solubles (DDGS) ${ }^{1}$

\begin{tabular}{|c|c|c|c|c|c|c|c|c|}
\hline \multirow[b]{2}{*}{ Item } & \multicolumn{4}{|c|}{ Diet } & \multirow[b]{2}{*}{ SEM } & \multicolumn{3}{|c|}{$P$-value ${ }^{2}$} \\
\hline & Control & $10 \%$ DDGS & $15 \%$ DDGS & $20 \%$ DDGS & & Diet & Linear & Quadratic \\
\hline Total, $\mathrm{kg} / \mathrm{d}$ & 40.7 & 42.2 & 42.0 & 44.4 & 4.26 & 0.40 & 0.20 & 0.78 \\
\hline Total N, g/d & 374 & 350 & 342 & 356 & 22.5 & 0.78 & 0.56 & 0.42 \\
\hline Total N, \% of $\mathrm{N}$ intake & 40.3 & 38.0 & 36.6 & 38.2 & 1.36 & 0.36 & 0.20 & 0.22 \\
\hline \multicolumn{9}{|l|}{ Fecal excretion } \\
\hline $\mathrm{DM}, \mathrm{kg} / \mathrm{d}$ & 9.04 & 9.34 & 9.23 & 9.47 & 0.19 & 0.14 & 0.05 & 0.78 \\
\hline $\mathrm{OM}, \mathrm{kg} / \mathrm{d}$ & 8.11 & 8.53 & 8.55 & 8.70 & 0.16 & 0.18 & 0.09 & 0.30 \\
\hline $\mathrm{N}, \mathrm{g} / \mathrm{d}$ & 231 & 241 & 247 & 249 & 6.5 & 0.21 & 0.06 & 0.53 \\
\hline $\mathrm{N}, \%$ of $\mathrm{N}$ intake & 25.5 & 25.5 & 26.7 & 26.9 & 0.92 & 0.59 & 0.22 & 0.95 \\
\hline \multicolumn{9}{|l|}{ Total N excretion } \\
\hline $\mathrm{g} / \mathrm{d}$ & 628 & 610 & 555 & 599 & 18.3 & 0.14 & 0.12 & 0.13 \\
\hline $\mathrm{ADF}$ & 45.0 & 42.6 & 47.0 & 45.3 & 1.73 & 0.28 & 0.48 & 0.85 \\
\hline $\mathrm{NDF}$ & 46.5 & 45.0 & 48.1 & 47.0 & 1.35 & 0.24 & 0.33 & 0.82 \\
\hline
\end{tabular}

${ }^{\mathrm{ab}}$ Means within a row with different superscripts differ $(P<0.05)$.

${ }^{1}$ Values are least squares means obtained from 4 ruminally cannulated cows.

${ }^{2} P$-values indicate overall diet, linear, and quadratic effects.

SP than in FP and LP, respectively. The mean iNDF concentration was 6.3 times greater in LP than in SP. These results clearly indicate that the concentrations of the 3 principal markers were distinctly greater in their respective digesta phases, so marker dysfunction was likely not a problem. Titgemeyer (1997) suggested that omasal sampling data can be validated by determining how well it compares with reliable estimates published in the literature and whether it falls within biological limits. Our estimates of omasal flows of DM and OM ranged from 22.3 to $24.2 \mathrm{~kg} / \mathrm{d}$ and from 18.0 to 19.5 $\mathrm{kg} / \mathrm{d}$, respectively. These estimates are greater than those from published studies using similar marker techniques and omasal sampling (see Reynal and Broderick, 2005; Brito et al., 2006; Brito et al., 2007a,b), possibly reflecting the much greater DM intakes $(30 \mathrm{~kg} / \mathrm{d}$ ) that were observed in the present study compared with those previous studies in which DM intakes were usually $\leq 24$ $\mathrm{kg} / \mathrm{d}$. Greater DM intakes result in high passage rates and high omasal flows of DM and OM (Brito et al., 2006). Apparent digestion of DM in the rumen, when expressed as absolute amounts or as a proportion of intake, was unaffected by diet and ranged from 6.24 to $7.36 \mathrm{~kg} / \mathrm{d}$ and from 20.4 to $24.8 \%$, respectively. The proportion of DM intake that was apparently digested in the rumen in the present study was lower than data obtained by other workers in dairy cows (33 to $36 \%$, Brito et al., 2006; 36 to 38\%, Olmos Colmenero and
Broderick, 2006; 35 to 42\%, Brito et al., 2007b). Again, these discrepant results likely reflect the large differences in DM intakes among studies; the much greater DM intakes in our study resulted in high passage rates and, consequently, lower extents of ruminal digestion (Brito et al., 2006). When expressed as a proportion of $\mathrm{OM}$ intake, the apparent and true digestion of $\mathrm{OM}$ in the rumen ranged from 33.4 to $37.3 \%$ and from 59.6 to $63.8 \%$, respectively, and these data fall within the ranges of 30 to $60 \%$ and 40 to $70 \%$ for ruminal apparent and true digestion, respectively, that are considered to be typical (Titgemeyer, 1997). Diet had no effect on apparent ruminal or total-tract NDF and ADF digestion; however, it should be noted that apparent ruminal $\mathrm{NDF}$ digestion (mean $=39.1 \%$ ) represented $83 \%$ of total-tract NDF digestion $($ mean $=46.7 \%)$. Titgemeyer (1997) suggested that at least $80 \%$ of total-tract NDF digestion should occur in the rumen when ruminants are fed by-products and good quality forage. The fact that our estimates of the proportion of dietary NDF that was digested in the rumen compare favorably with estimates derived using other experimental techniques (e.g., duodenal sampling) and modeling approaches (see Titgemeyer, 1997; Huhtanen et al., 2010) suggests that problems with unrepresentative omasal digesta sampling or marker dysfunction were not encountered in the present study; thus, we can surmise that our measurements of omasal flow are reliable. 
The dietary inclusion of W-DDGS in the current study had no effect on $\mathrm{N}$ intake, reflecting the similar dietary CP contents and DM intakes for the 4 ruminally cannulated cows that were used in the metabolism study. Because of similar $\mathrm{N}$ intakes, the flow of $\mathrm{N}$ at the omasal canal was similar across diets. Others (Brito et al., 2007a,b, 2009) have also reported that omasal N flow parallels $\mathrm{N}$ intake. The amount of dietary $\mathrm{N}$ that was apparently digested in the rumen did not change and was negative for all diets, indicating that omasal $\mathrm{N}$ flow was greater than $\mathrm{N}$ intake. In a meta-analytical study (Broderick et al., 2010) involving 32 experiments in which cattle were fed diets containing (\% of DM) 9.9 to $23.7 \% \mathrm{CP}, 7.5$ to $17.7 \% \mathrm{RDP}$, and 2.3 to $9.8 \%$ RUP, it was estimated that zero ruminal $\mathrm{N}$ balance (i.e., when omasal $\mathrm{N}$ flow $=\mathrm{N}$ intake) occurred when dietary $\mathrm{CP}$ and RDP contents were 14.7 and $10.6 \%$, respectively, and ruminal $\mathrm{N}$ balance became more positive as dietary $\mathrm{CP}$ and RDP contents increased. In the present study, mean dietary $\mathrm{CP}$ and RDP contents were 18.9 and $12.1 \%$, respectively, so ruminal $\mathrm{N}$ balance would be expected to be positive based on the observations of Broderick et al. (2010). Others (Reynal et al., 2003; Olmos Colmenero and Broderick, 2006) have reported negative apparent $\mathrm{N}$ digestion in the rumen when dairy cows were fed diets containing $>18 \% \mathrm{CP}$ and this can be attributed to the $\mathrm{N}$ contribution of recycled urea- $\mathrm{N}$ in the rumen (Broderick et al., 2008). Even when dietary $\mathrm{CP}$ content exceeds $17 \%$, our research group has demonstrated that substantial amounts of urea-N can be recycled to the rumen (Gozho et al., 2008). When ruminal $\mathrm{N}$ digestion was corrected for omasal outflow of microbial NAN, the amount of dietary $\mathrm{N}$ that was truly digested in the rumen was also unchanged by diet; however, when expressed as a proportion of $\mathrm{N}$ intake, a linear decrease in true $\mathrm{N}$ digestion in the rumen was observed as CM was replaced as the major protein source with increasing amounts of W-DDGS. As a result, the supply of RDP decreased linearly from 3,805 to 3,472 $\mathrm{g} / \mathrm{d}$ for cows fed the control (0\% W-DDGS) and $20 \%$ W-DDGS diets, respectively, representing a decrease from 12.7 to $11.6 \%$ when RDP supply is expressed as a proportion of DM intake. This response in RDP supply largely reflects the higher RUP content of W-DDGS (54\% of CP; Nuez-Ortín and Yu, 2009) compared with CM (40\% of CP; Piepenbrink and Schingoethe, 1998). A decrease in dietary RDP supply below the recommended 9.5 to $10.5 \%$ of DM (NRC, 2001) can depress microbial protein synthesis due to a deficiency in ruminal $\mathrm{NH}_{3}-\mathrm{N}$, and total free AA and peptides (Broderick et al., 2007). A shortcoming of the present study is that diets contained almost $19 \% \mathrm{CP}$, primarily because of the high CP content of W-DDGS, which made it difficult to formulate diets containing lower CP contents. Because of the high dietary CP levels, RDP supply in diets containing increasing levels of W-DDGS was still above the current recommended levels (NRC, 2001) which would mask any potential responses to changes in RDP supply. With lower CP diets, Reynal and Broderick (2005) reported greater microbial protein yields when RDP supply was increased. Further evidence that RDP supply was not limited by the dietary inclusion of W-DDGS is provided by the fact that ruminal $\mathrm{NH}_{3^{-}}$ $\mathrm{N}$ concentrations did not change with diet and, at all sampling times (data not shown) during a 24-h feeding cycle, were always greater than $5 \mathrm{mg} / \mathrm{dL}$, which has been suggested as the minimum ruminal $\mathrm{NH}_{3}-\mathrm{N}$ concentration that is required for maximum microbial protein synthesis (Satter and Slyter, 1974). Although other studies (Balcells et al., 1993; Reynal and Broderick, 2005) have reported higher concentrations of ruminal $\mathrm{NH}_{3}-\mathrm{N}(11 \mathrm{mg} / \mathrm{dL})$ as being necessary to optimize microbial protein synthesis, it is noteworthy that ruminal $\mathrm{NH}_{3}-\mathrm{N}$ concentrations on all diets were above $10 \mathrm{mg} / \mathrm{dL}$ at all sampling times during a 24-h feeding cycle and it is unlikely that replacing CM with W-DDGS would have caused a ruminal $\mathrm{NH}_{3}-\mathrm{N}$ deficiency. Although ruminal $\mathrm{NH}_{3}-\mathrm{N}$ is the major source of $\mathrm{N}$ for microbial growth (Brito et al., 2007a), clear evidence exists that the ruminal availability of preformed AA and peptides can stimulate microbial growth in vivo (Chikunya et al., 1996) and in in vitro cultures (Argyle and Baldwin, 1989; Carro and Miller, 1999). In the current study, we did not measure ruminal AA and peptide concentrations, but it is unlikely that the ruminal availability of AA and peptides could have limited microbial growth because RDP supply was well within the recommended levels (NRC, 2001). Clearly, more research is warranted in which dairy cows are fed diets containing W-DDGS and formulated to contain 16 to $17 \% \mathrm{CP}$.

Omasal flow of NAN, when expressed as grams per day, tended to increase linearly when increasing amounts of W-DDGS were added to the diet. Because $\mathrm{N}$ intakes and omasal flow of microbial NAN were similar across diets, this response can be attributed to greater amounts of dietary protein escaping ruminal degradation with increasing amounts of W-DDGS being included in the diet. In addition, we observed a quadratic increase in the omasal flow of NANBN, which is collectively composed of RUP and endogenous protein. The omasal flow of NANBN accounted for 24 to $28.6 \%$ of total NAN flow, which falls within the range been reported by others (Brito et al., 2006, 2007a,b). Because RUP is the major contributor to NANBN flow, 
the increased supply of RUP when increasing amounts of W-DDGS were added to the diet accounts for the greater omasal flows of NANBN with W-DDGS.

Maximizing the intestinal supply of microbial protein is important for high-producing dairy cows, so a major objective of the current study was to determine the effects of replacing CM with W-DDGS on microbial NAN supply. Omasal flows of FAB NAN and PAB NAN, when expressed as grams per day, were similar across diets and, thus, the omasal flow of total bacterial NAN (i.e., FAB NAN plus PAB NAN) was not different. The lack of significant effects of replacing $\mathrm{CM}$ with W-DDGS on bacterial NAN supply likely reflects that 11 to $12.7 \%$ RDP in diets containing CM or W-DDGS was adequate to support ruminal microbial growth. Not surprisingly, across all diets, 71 to $76 \%$ of total NAN in omasal digesta was of bacterial origin. Although the relative contribution of bacterial NAN to total NAN flow can vary considerably depending primarily on dietary and ruminal conditions that influence microbial growth, this range is in close agreement with data obtained by other workers in dairy cows (69 to $74 \%$, Olmos Colmenero and Broderick, 2006; 67 to $79 \%$, Brito et al., 2007a). When expressed as a proportion of total bacterial NAN flow, omasal flows of PAB NAN and FAB NAN contributed 44 to $49 \%$ and 46 to $51 \%$, respectively, of total bacterial NAN flow and did not differ with diet. In other studies, PAB NAN and FAB NAN contributed, respectively, 55 and $45 \%$ (Brito et al., 2006) and 57 and 43\% (Reynal and Broderick, 2005) of total bacterial NAN flow, which is in close agreement with our data. To our knowledge, this is the first study reporting the effects of replacing CM with W-DDGS on omasal flows of total NAN and bacterial NAN, so direct comparisons of our data with other published data with W-DDGS are not possible. Furthermore, only a few studies (Janicek et al., 2008; Kelzer et al., 2009) have reported effects on microbial $\mathrm{N}$ flow to the small intestine when C-DDGS is included in diets fed to dairy cows. Although the inclusion of 30\% C-DDGS decreased RDP supply, duodenal microbial N flow was not suppressed (Janicek et al., 2008). Similarly, Kelzer et al. (2009) did not observe any detrimental effects of feeding 15\% C-DDGS on duodenal microbial N supply. In the present study, our estimates of omasal flows of bacterial NAN ranged from 688 to $743 \mathrm{~g} / \mathrm{d}$ and were greater than microbial $\mathrm{N}$ yields that were reported previously in dairy cows fed C-DDGS (256 to 270 g/d, Janicek et al., 2008; 158 to 200 g/d, Kelzer et al., 2009). This discrepancy in results could be accounted for, among other numerous factors, by methodological differences in markers that were used to measure microbial NAN yields (Brito et al., 2006). Janicek et al.
(2008) and Kelzer et al. (2009) estimated microbial N supply indirectly by using urinary excretion of purine derivatives, whereas ${ }^{15} \mathrm{~N}$ was used in the current study. It is clearly established that using urinary purine derivative excretion grossly underestimates microbial yields compared with ${ }^{15} \mathrm{~N}$ as a microbial marker (Reynal et al., 2005; Brito et al., 2006). Additionally, there is a positive correlation between postruminal microbial $\mathrm{N}$ flow and DM intake (Moorby et al., 2006; Broderick et al., 2010). Cows in the present study consumed 4.0 to $6.7 \mathrm{~kg} / \mathrm{d}$ more DM compared with those in the studies of Janicek et al. (2008) and Kelzer et al. (2009), and these large differences in DM intakes could partly account for the disparity in estimates of microbial $\mathrm{N}$ supply. In numerous studies conducted with lactating dairy cows under a wide range of dietary conditions, estimates of microbial NAN supply obtained using ${ }^{15} \mathrm{~N}$ as a microbial marker and omasal sampling ranged from 375 to $480 \mathrm{~g} / \mathrm{d}$ (Olmos Colmenero and Broderick, 2006; Brito et al., 2006; Brito et al., 2007b), which are still lower compared with estimates reported in the current study. Again, large differences in DM intake and other factors (e.g., source and amount of both dietary $\mathrm{N}$ and carbohydrate, ruminal dilution rate, ruminal $\mathrm{pH}$ ) that influence ruminal microbial growth account for discrepant estimates of microbial NAN flow. Microbial NAN flows determined with omasal sampling and using an HPLC or spectrophotometric assay for purine analysis ranged from 239 to $717 \mathrm{~g} / \mathrm{d}$ and from 302 to $740 \mathrm{~g} / \mathrm{d}$, respectively (Reynal et al., 2003), indicating that our estimates are not unrealistic.

Microbial efficiency averaged $39.8 \mathrm{~g} / \mathrm{kg}$ of OMTDR across diets in the current study and was higher than the range of 13.5 to $30.8 \mathrm{~g} / \mathrm{kg}$ of OMTDR that was reported in a meta-analytical review of ruminal $\mathrm{N}$ metabolism data from studies using the omasal sampling technique under varied dietary conditions (Broderick et al., 2010). A major determinant of microbial efficiency is DM intake. An increase in DM intake leads to a decrease in the rumen retention time of microbes and, thus, a decrease in microbial maintenance energy requirements, which would then result in an increase in microbial efficiency (Russell et al., 1992). In the present study, DM intake was greater than the range of 6.0 to $27.4 \mathrm{~kg} / \mathrm{d}$ in DM intake that was reported in those studies used in the meta-analysis by Broderick et al. (2010), thus possibly accounting for our greater estimates of microbial efficiency. Microbial efficiency was not suppressed when W-DDGS was added to diets. Besides a requirement for $\mathrm{N}$, rumen microbes also require energy primarily supplied by the fermentation of $\mathrm{OM}$ (Clark et al., 1992; Ipharraguerre et al., 2005). Feeding W-DDGS had no effect on OM truly digested in the 
rumen, which averaged $62 \%$ across dietary treatments, so we can surmise that energy availability did not limit microbial growth in diets containing W-DDGS.

Although W-DDGS is a good source of digestible RUP, its lysine content especially is lower compared with that of CM (Boila and Ingalls, 1994). Together, lysine and methionine are the 2 most limiting amino acids for milk and milk protein production on a wide variety of diets that are typically fed to dairy cows in North America (Schwab et al., 1992), so the major challenge when feeding W-DDGS as a substitute for $\mathrm{CM}$ is providing a sufficient amount of lysine (Boila and Ingalls, 1994; Mulrooney et al., 2009; Schingoethe et al., 2009). Because dietary lysine content decreased from 0.926 to $0.593 \%$ of DM when dietary W-DDGS was increased from 0 to $20 \% \mathrm{~W}$-DDGS (reflecting the lower lysine content of W-DDGS compared with CM), and because DM intakes were similar for cows that were used in the metabolism study, lysine intake (data not shown) decreased when W-DDGS replaced CM. We had anticipated that this decrease in lysine intake coupled with a higher RUP supply primarily from lysinedeficient W-DDGS would result in a decrease in lysine supply at the omasal canal. However, this was not the case as omasal lysine flows were unaffected by diet, and the reasons for these observations are not clear. Amino acids in omasal digesta are primarily contributed by microbial NAN and feed protein that escapes ruminal degradation (i.e., RUP), plus small amounts of endogenous protein (NRC, 2001). As microbial NAN supply was not altered by diet, we can surmise that omasal lysine supply from that source was roughly equal across diets; consequently, it is plausible that a greater RUP supply as more W-DDGS was fed could have increased omasal lysine supply. Both methionine intake and omasal flow were unaffected when W-DDGS replaced CM. Based on NRC (2001), the ideal lysine:methionine ratio for optimum use of MP for both maintenance and milk protein production is $3: 1$. Across dietary treatments, the lysine:methionine ratio in omasal digesta ranged from 3.12:1 to 3.67:1, well above the NRC (2001) recommendation and suggesting that both lysine and methionine were not limiting in the present study. However, it should be noted that these lysine:methionine ratios were calculated from measured omasal flows of lysine and methionine, and do not account for intestinal digestibility.

When DM intakes for all 8 cows that were used in the study were included in the statistical analysis, feeding W-DDGS resulted in a linear increase in DM intake. This response in DM intake is somewhat different from that observed in the metabolism study (with only 4 cows) where no differences in DM intake were observed, possibly reflecting the differences in sample size. In a limited number of studies, the inclusion of W-DDGS (Zhang et al., 2010a) or a corn/wheat-based DDGS (produced from $70 \%$ corn and 30\% wheat; Zhang et al., 2010b) at $20 \%$ of diet DM increased DM intake by 3.0 to $3.6 \mathrm{~kg} / \mathrm{d}$; however, it should be noted that these studies did not involve feeding graded levels of DDGS. In the current study, the inclusion of up to $20 \% \mathrm{~W}$ DDGS linearly increased DM intake by 0.3 to $2.1 \mathrm{~kg} / \mathrm{d}$, a response that was lower than that reported in the studies of Zhang et al. (2010a,b). This difference in the magnitude of responses in DM intakes when W-DDGS is included in the diet could be attributed to the much lower DM intakes for control cows in those previous studies $(\sim 21.3 \mathrm{~kg} / \mathrm{d})$ compared with the current study $(29.7 \mathrm{~kg} / \mathrm{d})$, which could have limited responses in DM intake as it was already near maximal. In a study by Janicek et al. (2008), the partial replacement of both corn silage and concentrates with C-DDGS at 10, 20, and $30 \%$ of diet DM linearly increased DM intake, thus supporting our observations in the current study. It is not clear why DDGS increases DM intake when it partially replaces forage or concentrate in dairy diets. Compared with forages, DDGS has a smaller particle size (Zhang et al., 2010a). Because ration particle size is inversely related to DM intake (Kononoff and Heinrichs, 2003), the inclusion of DDGS as a partial replacement for forage could increase DM intake due to faster rates of passage (Allen and Grant, 2000). However, in the study by Zhang et al. (2010a), cows fed DDGS as a partial replacement for forage exhibited a slower rate of passage yet their DM intake was greater than in control animals. In the current study, greater DM intakes for cows fed W-DDGS were not accompanied by greater omasal flows or decreased total-tract nutrient digestibility, thus suggesting that faster rates of passage were not responsible for the greater DM intakes that were observed. It is possible that the effects of including DDGS on DM intake will depend on the type of feed ingredient that is replaced (Janicek et al., 2008). It should be noted that other studies have observed that partially replacing concentrate with DDGS had no effect on DM intake (Sasikala-Appukuttan et al., 2008; Mulrooney et al., 2009; Mjoun et al., 2010; Christen et al., 2010) or tended to reduce DM intake (Anderson et al., 2006).

In the current study, actual milk production increased by 1.2 to $1.8 \mathrm{~kg} / \mathrm{d}$ when W-DDGS replaced CM. These observations support previous studies in which the inclusion of W-DDGS (Zhang et al., 2010a) or a corn/wheat-based DDGS as a partial replacement for barley silage or concentrate increased milk yield by 2.8 to $3.4 \mathrm{~kg} / \mathrm{d}$, although the magnitude of response was different. Others (Anderson et al., 2006; Janicek et al., 2008) reported that feeding increasing amounts 
of C-DDGS resulted in more milk production, a response that was attributed to corresponding increases in DM intake. In the current study, the 0.3- to 2.1$\mathrm{kg} / \mathrm{d}$ increase in DM intake when W-DDGS was fed contributed an estimated 0.5 to $3.2 \mathrm{Mcal}$ of additional $\mathrm{NE}_{\mathrm{L}}$ intake. Assuming caloric values of 9.29, 5.71, and $3.95 \mathrm{Mcal} / \mathrm{kg}$ for fat, protein, and lactose (NRC, 2001) and using mean milk composition data for cows fed WDDGS (i.e., fat, protein, and lactose contents of 3.52, 3.30 , and $4.55 \%$, respectively; Table 3 ), the additional $\mathrm{NE}_{\mathrm{L}}$ intake would correspond to a $0.3-$ to $2.2-\mathrm{kg} / \mathrm{d}$ increase in milk yield. Therefore, it is likely that the $1.2-$ to $1.8 \mathrm{-kg} / \mathrm{d}$ increase in milk yield when cows were fed W-DDGS can be partly attributable to a greater DM intake compared with control cows. Milk protein content did not differ with diet, possibly reflecting that the dietary inclusion of W-DDGS had no detrimental effects on postruminal MP and EAA supply; however, milk protein yield changed quadratically with the inclusion of W-DDGS. Any diet-induced changes in omasal NAN flow because of differences in the contributions of either NANBN or microbial NAN flow can result in changes in milk protein yield (Broderick et al., 2010); therefore, the increase in NANBN and NAN flowing at the omasum when feeding W-DDGS could have contributed to the change in milk protein yield. In addition, the greater milk protein yield with feeding W-DDGS could be partly attributed to the increase in milk yield. Milk N efficiency ranged from 24.1 to $25.2 \%$, which is typical for cows fed high CP diets (NRC, 2001). Milk fat percentage, which is an indirect indicator of rumen health, did not change when CM replaced W-DDGS. All diets fed in this study were formulated to contain $50 \%$ forage and provided an adequate amount of physically effective fiber to maintain rumen function and prevent milk fat depression. Penner et al. (2009) did not observe changes in either chewing activity or milk fat concentration when feeding 10\% W-DDGS as a partial replacement for concentrate in diets that contained $50 \%$ forage. According to Schingoethe et al. (2009), up to $40 \%$ DDGS can be included in dairy rations without causing milk fat depression, provided the diets contain an adequate amount of physically effective fiber. Feeding DDGS-containing diets with forage and forage NDF contents below 50 and $22 \%$, respectively, can result in milk fat depression (Kalscheur, 2005). Zhang et al. (2010a) reported a decrease in ruminal $\mathrm{pH}$ and milk fat concentration as a result of a decrease in dietary forage NDF and physically effective fiber content when W-DDGS replaced barley silage.

Wheat-based DDGS is high in NDF that is highly digestible, so it can be considered as a nonforage fiber source (Zhang et al., 2010a). In conjunction with its very low starch content, these characteristics of
W-DDGS have led to recent studies (Zhang et al., 2010a,b) that have examined if feeding W-DDGS as a partial replacement for forage or concentrate could potentially attenuate ruminal acidosis in dairy cows. Results from these studies indicate that when DDGS replaced barley silage or barley grain, ruminal acidosis was unaffected (Zhang et al., 2010b); however, partially replacing barley silage with DDGS worsened ruminal acidosis in a separate study (Zhang et al., 2010a). The consensus is that feeding DDGS as a partial replacement for barley silage or high starch concentrates has limited capacity in attenuating ruminal acidosis (Beliveau and McKinnon, 2009; Zhang et al., 2010a,b) because the small particle size of DDGS decreases chewing activity and, in turn, salivary secretion. In the present study, W-DDGS replaced portions of protein ingredients and, not surprisingly, had no effect on ruminal $\mathrm{pH}$. Ruminal fermentation patterns were largely unaffected by the addition of W-DDGS. The lack of diet effects on ruminal acetate, butyrate, propionate, and total VFA concentrations following the inclusion of W-DDGS is in agreement with observations made in other studies (Anderson et al., 2006; Christen et al., 2010; Zhang et al., 2010b). In the present study, isobutyrate concentrations were lower in cows fed W-DDGS compared with those fed CM, thus supporting results from other studies (Zhang et al., 2010a). The higher intake of branched-chain AA in cows fed CM compared with those fed W-DDGS (data not shown) could have provided more precursors for branched-chain fatty acid synthesis (Johnson et al., 1994).

Although isonitrogenous diets were fed in the present study, changes in ruminal protein degradability were expected to affect $\mathrm{N}$ excretion. Increasing the amount of W-DDGS in the diet had no effect on total urinary $\mathrm{N}$ excretion, possibly reflecting the similar $\mathrm{N}$ intake across diets as a positive correlation exists between $\mathrm{N}$ intake and urine $\mathrm{N}$ loss (Castillo et al., 2001). Fecal excretion of $\mathrm{N}$ tended to increase linearly with the inclusion of W-DDGS. Cows fed W-DDGS also excreted $64 \%$ of consumed $\mathrm{N}$ in feces and urine, on average, which was lower than the $67 \%$ that was observed for cows receiving $0 \% \mathrm{~W}$-DDGS, possibly reflecting the decrease in RDP supply with W-DDGS. Overall, the effect of feeding W-DDGS as a substitute for CM on $\mathrm{N}$ loss to the environment was minimal.

\section{CONCLUSIONS}

Based on results from this study, W-DDGS can completely substitute for CM as the major protein source, and could be used as the main protein supplement in lactating cow diets. Inclusion of W-DDGS had no detrimental effects on ruminal fermentation, microbial 
protein production, or flow of nutrients at the omasal canal. Cows fed diets containing W-DDGS exhibited greater DM intakes and milk yields compared with those fed $\mathrm{CM}$ as the major protein source. In conclusion, up to $20 \% \mathrm{~W}$-DDGS can be added to lactating cow rations without negatively affecting ruminal function and can potentially increase DM intake and milk yield.

\section{ACKNOWLEDGMENTS}

The authors thank Marlene Fehr and staff of the Greenbrae Dairy Research Facility, University of Saskatchewan, for animal care and excellent technical assistance. We also thank Glen Broderick (US Dairy Forage Research Center, Madison, WI), Antonio Faciola (University of Wisconsin, Madison), and André Brito (University of New Hampshire, Durham) for their technical help with setting up the omasal sampling technique in our laboratory. This research was supported by the Government of Saskatchewan's Agriculture Development Fund (ADF).

\section{REFERENCES}

Ahvenjärvi, S., A. Vanhatalo, and P. Huhtanen. 2002. Supplementing barley or rapeseed meal to dairy cows fed grass-red clover silage: I. Rumen degradability and microbial flow. J. Anim. Sci. 80:2176-2187.

Ahvenjärvi, S., A. Vanhatalo, P. Huhtanen, and T. Varvikko. 2000. Determination of reticulo-rumen and whole-stomach digestion in lactating cows by omasal canal or duodenal sampling. Br. J. Nutr. 83:67-77.

Allen, D. M., and R. J. Grant. 2000. Interactions between forage and wet corn gluten feed as sources of fiber in diets for lactating dairy cows. J. Dairy Sci. 83:322-331.

Anderson, J. L., D. J. Schingoethe, K. F. Kalscheur, and A. R. Hippen. 2006. Evaluation of dried and wet distillers grains included at two concentrations in the diets of lactating dairy cows. J. Dairy Sci. 89:3133-3142.

AOAC. 1990. Official Methods of Analysis. 15th ed. Association of Official Analytical Chemist, Arlington, VA.

AOAC. 1995. Official Methods of Analysis. 16th ed. Association of Official Analytical Chemist, Arlington, VA.

Argyle, J. L., and R. L. Baldwin. 1989. Effects of amino acids and peptides on rumen microbial growth yields. J. Dairy Sci. 72:20172027.

Balcells, J., J. A. Guada, C. Castrillo, and J. Gasa. 1993. Rumen digestion and urinary excretion of purine derivatives in response to urea supplementation of sodium-treated straw fed to sheep. Br. J. Nutr. 69:721-732.

Beliveau, R. M., and J. J. McKinnon. 2009. Effect of graded levels of wheat-based dried distillers' grains with soluble on rumen fermentation in finishing cattle. Can. J. Anim. Sci. 89:513-520.

Binnerts, W. T., A. T. van't Klooster, and A. M. Frens. 1968. Soluble chromium indicator measure by atomic absorption in digestion experiments. Vet. Rec. 82:470-476.

Boila, R. J., and J. R. Ingalls. 1994. The post-ruminal digestion of dry matter, nitrogen and amino acids in wheat-based distillers dried grains and canola meal. Anim. Feed Sci. Technol. 49:173-188.

Brito, A. F., G. A. Broderick, J. J. Olmos Colmenero, and S. M. Reynal. 2007a. Effects of feeding formate-treated alfalfa silage or red clover silage on omasal nutrient flow and microbial protein synthesis in lactating dairy cows. J. Dairy Sci. 90:1392-1404.
Brito, A. F., G. A. Broderick, and S. M. Reynal. 2006. Effect of varying dietary ratios of alfalfa silage to corn silage on omasal flow and microbial protein synthesis in dairy cows. J. Dairy Sci. 89:39393953.

Brito, A. F., G. A. Broderick, and S. M. Reynal. 2007b. Effects of different protein supplements on omasal nutrient flow and microbial protein synthesis in lactating dairy cows. J. Dairy Sci. 90:1828-1841.

Brito, A. F., G. F. Tremblay, H. Lapierre, A. Bertrand, Y. Castonguay, G. Bélanger, R. Michaund, C. Benchaar, D. R. Oullet, and R. Berthiaume. 2009. Alfalfa cut at sundown and harvested as baleage increases bacterial protein synthesis in late-lactation dairy cows. J. Dairy Sci. 92:1092-1107.

Broderick, G. A., A. F. Brito, and J. J. Olmos Colmenero. 2007. Effects of feeding formate-treated alfalfa silage or red clover silage on the production of lactating dairy cows. J. Dairy Sci. 90:1378-1391.

Broderick, G. A., P. Huhtanen, S. Ahvenjärvi, S. M. Reynal, and K. J. Shingfield. 2010. Quantifying ruminal N metabolism using the omasal sampling technique in cattle-A meta-analysis. J. Dairy Sci. 93:3216-3230.

Broderick, G. A., and J. H. Kang. 1980. Automated simultaneous determination of ammonia and total amino acids in ruminal fluid and in vitro media. J. Dairy Sci. 63:64-75.

Broderick, G. A., N. D. Luchini, S. M. Reynal, G. A. Varga, and V. A. Ishler. 2008. Effect on production of replacing dietary starch with sucrose in lactating dairy cows. J. Dairy Sci. 91:4801-4810.

Carro, M. D., and E. L. Miller. 1999. Effect of supplementing a fibre basal diet with different nitrogen forms on ruminal fermentation and microbial growth in an in vitro semi-continuous culture system (RUSITEC). Br. J. Nutr. 82:149-157.

Castillo, A. R., E. Kebreab, D. E. Beever, and J. France. 2001. A review of efficiency of nitrogen utilization in lactating dairy cows and its relationship with environmental pollution. J. Anim. Feed Sci. 9:1-32.

Chikunya, S., C. J. Newbold, L. Rode, X. B. Chen, and R. J. Wallace. 1996. Influence of dietary rumen-degradable protein on bacterial growth in the rumen of sheep receiving different energy sources. Anim. Feed Sci. Technol. 63:333-340.

Christen, K. A., D. J. Schingoethe, K. F. Kalscheur, A. R. Hippen, K. K. Karges, and M. L. Gibson. 2010. Response of lactating dairy cows to high protein distillers grains or 3 other protein supplements. J. Dairy Sci. 93:2095-2104.

Clark, J. H., T. H. Klusmeyer, and M. R. Cameron. 1992. Microbial protein synthesis and flows of nitrogen fractions to the duodenum of dairy cows. J. Dairy Sci. 75:2304-2323.

Dong, F. M., B. A. Rasco, and S. S. Gazzaz. 1987. A protein quality assessment of wheat and corn distillers dried grains with solubles. Cereal Chem. 64:327-332.

Erwin, E. S., G. J. Marco, and E. M. Emery. 1961. Volatile fatty acids analysis of blood and rumen fluid by gas chromatography. J. Dairy Sci. 44:1768-1776.

France, J., and R. C. Siddons. 1986. Determination of digesta flow by continuous marker infusion. J. Theor. Biol. 121:105-120.

Gozho, G. N., M. R. Hobin, and T. Mutsvangwa. 2008. Interactions between barley grain processing and source of supplemental dietary fat on nitrogen metabolism and urea-nitrogen recycling in dairy cows. J. Dairy Sci. 91:247-259.

Hickling, D. 2008. Maximized utilization of canola co-products in the livestock industry. Pages 3-14 in Proc. 29th Western Nutrition Conference, Edmonton, AB, Canada. University of Alberta, Edmonton, AB, Canada.

Hugli, T. E., and S. Moore. 1972. Determination of the tryptophan content of proteins by ion exchange chromatography of alkaline hydrolysates. J. Biol. Chem. 247:2828-2834.

Huhtanen, P., S. Ahvenjärvi, G. A. Broderick, S. M. Reynal, and K. J Shingfield. 2010. Quantifying ruminal digestion of organic matter and neutral detergent fiber using the omasal sampling technique in cattle - A meta-analysis. J. Dairy Sci. 93:3203-3215.

Huhtanen, P., P. G. Brotz, and L. D. Satter. 1997. Omasal sampling technique for assessing fermentative digestion in the forestomach of dairy cows. J. Anim. Sci. 75:1380-1392. 
Ipharraguerre, I. R., and J. H. Clark. 2005. Impacts of the source and amount of crude protein on the intestinal supply of nitrogen fractions and performance of dairy cows. J. Dairy Sci. 88(E Suppl.):E22-E37.

Ipharraguerre, I. R., J. H. Clark, and D. E. Freeman. 2005. Varying protein and starch in the diet of dairy cows. I. Effects of ruminal fermentation and intestinal supply of nutrients. J. Dairy Sci. $88: 2537-2555$.

Janicek, B. N., P. J. Kononoff, A. M. Gehman, and P. H. Doane. 2008. The effect of feeding dried distillers grains plus solubles on milk production and excretion of purine derivatives. J. Dairy Sci. 91:3544-3553.

Johnson, T. R., M. J. Cecava, E. B. Sheiss, and K. D. Cunningham. 1994. Additions of ruminally degradable crude protein and branched-chain volatile fatty acids to diets containing hydrolyzed feather meal and blood meal for lactating cows. J. Dairy Sci. $77: 3676-3682$.

Kalscheur, K. F. 2005. Impact of feeding distillers grains on milk fat, protein, and yield. Proc. Distillers Grains Technology Council 10th Annual Symposium, Louisville, KY.

Kelzer, J. M., P. J. Kononoff, A. M. Gehman, L. O. Tedeschi, K. Karges, and M. L. Gibson. 2009. Effects of feeding three types of corn-milling coproducts on milk production and ruminal fermentation of lactating Holstein cattle. J. Dairy Sci. 92:5120-5132.

Kononoff, P. J., and A. J. Heinrichs. 2003. The effect of reducing alfalfa haylage particle size on cows in early lactation. J. Dairy Sci. 86:1445-1457.

Marsh, W. H., B. Fingerhut, and E. Kirsch. 1957. Determination of urea nitrogen with the diacetyl method and an automatic dialyzing apparatus. Am. J. Clin. Pathol. 28:681-688.

McDougall, E. I. 1948. Studies on ruminant saliva. I. The composition and output of sheep's saliva. Biochem. J. 43:99-109.

McKinnon, J. J., and A. M. Walker. 2008. Comparison of wheat-based dried distillers' grain with solubles to barley as an energy source for backgrounding cattle. Can. J. Anim. Sci. 88:721-724.

Mjoun, K., K. F. Kalscheur, A. R. Hippen, and D. J. Schingoethe. 2010. Performance and amino acid utilization of early lactation dairy cows fed regular or reduced-fat dried distillers grains with solubles. J. Dairy Sci. 93:3176-3191.

Moorby, J. M., R. J. Dewhurst, R. T. Evans, and J. L. Danelon. 2006. Effects of dairy cow diet forage proportion on duodenal nutrient supply and urinary purine derivative excretion. J. Dairy Sci. 89:3552-3562.

Mulrooney, C. N., D. J. Schingoethe, K. F. Kalscheur, and A. R. Hippen. 2009. Canola meal replacing distillers grains with solubles for lactating dairy cows. J. Dairy Sci. 92:5669-5676.

National Research Council. 2001. Nutrient Requirements of Dairy Cattle. 7th rev. ed. National Academy Press, Washington, DC.

Nuez Ortín, W., and P. Yu. 2009. Nutrient variation and availability of wheat DDGS, corn DDGS and blend DDGS from bioethanol plants. J. Sci. Food Agric. 89:1754-1761.

Olmos Colmenero, J. J., and G. A. Broderick. 2006. Effect of dietary crude protein concentration on ruminal nitrogen metabolism in lactating dairy cows. J. Dairy Sci. 89:1694-1703.

Orth, R. 1992. Sample day and lactation report. DHIA 200 Fact Sheet A-2. Mid-states DRPC, Ames, IA.

Penner, G. B., K. A. Beauchemin, and T. Mutsvangwa. 2006. An evaluation of the accuracy and precision of a stand-alone submersible continuous ruminal pH measurement system. J. Dairy Sci. 89:2132-2140.

Penner, G. B., P. Yu, and D. A. Christensen. 2009. Effect of replacing forage or concentrate with wet or dry distillers' grains on productivity and chewing activity of dairy cattle. Anim. Feed Sci. Technol. 153:1-10

Piepenbrink, M. S., and D. J. Schingoethe. 1998. Ruminal degradation, amino acid composition, and estimated intestinal digestibilities of four protein supplements. J. Dairy Sci. 81:454-461.
Plaizier, J. C., J. P. Walton, A. Martin, T. Duffield, R. Bagg, P. Dick, and B. W. McBride. 2000. Short communication: Effects of monensin on 3-MH excretion in transition dairy cows. J. Dairy Sci. 83:2810-2812.

Reynal, S. M., and G. A. Broderick. 2005. Effect of dietary level of rumen-degraded protein on production and nitrogen metabolism in lactating dairy cows. J. Dairy Sci. 88:4045-4064.

Reynal, S. M., G. A. Broderick, S. Ahvenjärvi, and P. Huhtanen. 2003. Effect of feeding protein supplements of differing degradability on omasal flow of microbial and undegraded protein. J. Dairy Sci. $86: 1292-1305$.

Reynal, S. M., G. A. Broderick, and C. Bearzi. 2005. Comparison of four markers for quantifying microbial protein flow from the rumen of lactating dairy cows. J. Dairy Sci. 88:4065-4082.

Russell, J. B., J. D. O'Connor, D. G. Fox, P. J. Van Soest, and C. J Sniffen. 1992. A net carbohydrate and protein system for evaluating cattle diets: I. Ruminal fermentation. J. Anim. Sci. 70:35513561.

SAS Institute. 2002. User's Guide. Statistics. Version 9. SAS Institute Inc., Cary, NC.

Sasikala-Appukuttan, A. K., D. J. Schingoethe, A. R. Hippen, K. F. Kalscheur, K. Karges, and M. L. Gibson. 2008. The feeding value of corn distillers solubles for lactating dairy cows. J. Dairy Sci. 91:279-287.

Satter, L. D., and L. L. Slyter. 1974. Effect of ammonia concentration on rumen microbial protein production in vitro. Br. J. Nutr. 32:199-208.

Schingoethe, D. J., K. F. Kalscheur, A. R. Hippen, and A. D. Varga. 2009. Invited review: The use of distillers products in dairy cattle diets. J. Dairy Sci. 92:5802-5813.

Schwab, C. G., C. K. Bozak, and N. L. Whitehouse. 1992. Amino acid limitation and flow to the duodenum at four stages of lactation. 1. Sequence of lysine and methionine limitation. J. Dairy Sci. $75: 3486-3502$

Siddons, R. C., J. Paradine, D. E. Beever, and P. R. Cornell. 1985. Ytterbium acetate as a particulate-phase digesta-flow marker. Br. J. Nutr. 54:509-519.

Stern, M. D., A. Bach, and S. Calsamiglia. 2006. New concepts in protein nutrition of ruminants. Pages 45-66 in 21st Annual Southwest Nutrition and Management Conference. University of Arizona, Tempe.

Titgemeyer, E. C. 1997. Design and interpretation of nutrient digestion studies. J. Anim. Sci. 75:2235-2247.

Udén, P., P. E. Colucci, and P. J. Van Soest. 1980. Investigation of chromium, cerium and cobalt as markers in digesta: Rate of passage studies. J. Sci. Food Agric. 31:625-632

Van Soest, P. J., J. B. Robertson, and B. A. Lewis. 1991. Methods for dietary fiber, neutral detergent fiber, and non-starch polysaccharides in relation to animal nutrition. J. Dairy Sci. 74:3593-3597.

Vicente, F., A. Sarraseca, A. de Vega, and J. A. Guada. 2004. Performance of several $\mathrm{Cr}$ and $\mathrm{Yb}$ analytical techniques applied to samples of different biological origin (digesta or faeces). J. Sci. Food Agric. 84:2035-2040.

Zhang, S. Z., G. B. Penner, M. Abdelqader, and M. Oba. 2010a. Effects of feeding alfalfa hay on chewing, rumen $\mathrm{pH}$, and milk fat concentration of dairy cows fed wheat dried distillers grains with solubles as a partial substitute for barley silage. J. Dairy Sci. 93:3243-3252.

Zhang, S. Z., G. B. Penner, W. Z. Yang, and M. Oba. 2010b. Effects of partially replacing barley silage or barley grain with dried distillers grains with soluble on rumen fermentation and milk production of lactating dairy cows. J. Dairy Sci. 93:3231-3242. 